\title{
Deep-water turbidites as Holocene earthquake proxies: the Cascadia subduction zone and Northern San Andreas Fault systems
}

Chris Goldfinger $\left({ }^{1}\right)$, C. Hans Nelson $\left({ }^{2}\right)\left({ }^{*}\right)$, Joel E. Johnson $\left({ }^{1}\right)$ and the Shipboard Scientific Party

$\left.{ }^{1}\right)$ College of Oceanic and Atmospheric Sciences, Oregon State University, Corvallis, Oregon, U.S.A.

${ }^{2}{ }^{2}$ Department of Oceanography, Texas A \& M University, College Station, Texas, U.S.A.

\begin{abstract}
New stratigraphic evidence from the Cascadia margin demonstrates that 13 earthquakes ruptured the margin from Vancouver Island to at least the California border following the catastrophic eruption of Mount Mazama. These 13 events have occurred with an average repeat time of $\sim 600$ years since the first post-Mazama event $\sim 7500$ years ago. The youngest event $\sim 300$ years ago probably coincides with widespread evidence of coastal subsidence and tsunami inundation in buried marshes along the Cascadia coast. We can extend the Holocene record to at least 9850 years, during which 18 events correlate along the same region. The pattern of repeat times is consistent with the pattern observed at most (but not all) localities onshore, strengthening the contention that both were produced by plate-wide earthquakes. We also observe that the sequence of Holocene events in Cascadia may contain a repeating pattern, a tantalizing look at what may be the long-term behavior of a major fault system. Over the last $\sim 7500$ years, the pattern appears to have repeated at least three times, with the most recent A.D. 1700 event being the third of three events following a long interval of 845 years between events T4 and T5. This long interval is one that is also recognized in many of the coastal records, and may serve as an anchor point between the offshore and onshore records. Similar stratigraphic records are found in two piston cores and one box core from Noyo Channel, adjacent to the Northern San Andreas Fault, which show a cyclic record of turbidite beds, with thirty-one turbidite beds above a Holocene/Pleistocene faunal «datum». Thus far, we have determined ages for 20 events including the uppermost 5 events from these cores. The uppermost event returns a «modern» age, which we interpret is likely the 1906 San Andreas earthquake. The penultimate event returns an intercept age of A.D. 1664 (2 $\sigma$ range 15051822). The third event and fourth event are lumped together, as there is no hemipelagic sediment between them. The age of this event is A.D. 1524 (1445-1664), though we are not certain whether this event represents one event or two. The fifth event age is A.D. 1204 (1057-1319), and the sixth event age is A.D. 1049 (981-1188). These results are in relatively good agreement with the onshore work to date, which indicates an age for the penultimate event in the mid-1600's, the most likely age for the third event of $\sim 1500-1600$, and a fourth event $\sim 1300$. We presently do not have the spatial sampling needed to test for synchroneity of events along the Northern San Andreas, and thus cannot determine with confidence that the observed turbidite record is earthquake generated. However, the good agreement in number of events between the onshore and offshore records suggests that, as in Cascadia, turbidite triggers other than earthquakes appear not to have added significantly to the turbidite record along the northernmost San Andreas margin during the last $\sim 2000$ years.
\end{abstract}

Key words paleoseismology-earthquake - submarinerecurrence patterns - submarine landslides - turbid flows

Mailing address: Dr. Chris Goldfinger, College of Oceanic and Atmospheric Sciences, Oregon State University, Marine Geology Active Tectonics Group, Ocean Admin. Bldg. 104, Corvallis, Oregon 97331, U.S.A.; e-mail: gold@coas.oregonstate.edu

(*) Now at: Instituto Andaluz de Ciencias de la Tierra, CSIC, Universidad de Granada, Campus de Fuente Nueva s/n, Granada 18071, Spain.

\section{Introduction}

The study of plate boundary fault systems has been revolutionized by two relatively recent sub-disciplines: paleoseismology and crustal motion as measured by the Global Positioning System. GPS technology now makes it possible to measure crustal strain accumulation at plate boundaries with a high degree of certainty in 
only a few years. However, real-time strain measurements can only represent a fraction of one strain cycle. Fundamental questions such as the utility of the seismic gap hypothesis, clustering, and the applicability of slip-predictable or time-predictable models remain unanswered because we rarely have a long enough earthquake record. Characteristic earthquake models assume that stress buildup is proportional to the time since the last earthquake. The seismic gap hypothesis follows directly from this assumption, and is the basis for probabilistic predictions of seismicity. Recently, characteristic earthquake models and their derivatives have been challenged by new models of stress-triggering and fault interaction. In these models, strain recharge following an earthquake is supplied only indirectly by the underlying motion of the plates, and the stress on each fault segment is controlled by the action and history of the surrounding segments (e.g. Stein et al., 1992; Ward and Goes, 1993). The applicability of these models may well be system dependent, may differ between plate boundary versus crustal faults, or depend on magnitude. What is needed most to address these questions is data on spatial and temporal earthquake recurrence for more fault systems and over longer spans of time, so that meaningful statistical conclusions can be drawn.

Paleoseismology can address these questions on active continental margins. Two methodologies used in recent years are coastal paleoseismology and investigation of the turbidite event history. Unlike more typical paleoseismology on land, neither technique uses fault outcrops because the faults are entirely offshore, and both techniques must demonstrate that the events they are investigating are uniquely generated by earthquakes and not some other natural phenomenon. Nevertheless, these problems can be overcome, and both techniques can be powerful tools for deciphering the earthquake history along an active continental margin. The turbidite record has the potential to extend and earthquake history farther back in time than coastal records, $\sim 10000$ years, more than enough to encompass many earthquake cycles. In recent years, turbidite paleoseismology has been attempted in Cascadia (Adams, 1990; Goldfinger and Nelson, 1999; Goldfinger et al., 2003; Nelson et al., 2003),
Puget Sound (Karlin and Abella, 1992), Japan (Inouchi et al., 1996), the Mediterranean (Kastens, 1984; Anastasakis and Piper, 1991; Nelson C.H. et al., 1995), the Dead Sea (Niemi and Ben-Avraham, 1994), Northern California (Field, 1984) and even the Arctic ocean (Grantz et al., 1996), and is a technique that is evolving as a precise tool for seismotectonics.

We have been investigating the use of turbidites as paleo-earthquake proxies at the Cascadia subduction zone and along the Northern San Andreas Fault. A growing body of evidence from both of these margin settings suggests that with favorable physiography and sedimentological conditions, turbidites can be used as earthquake proxies with careful spatial and temporal correlations.

New stratigraphic evidence from the $\mathrm{Ca}$ scadia margin confirms that 13 turbidites were deposited in major channel systems along the margin from Vancouver Island to at least the California border (Adams, 1990) following the catastrophic eruption of Mount Mazama. Nelson et al. (2003) have interpreted these turbidites as having been triggered by great subduction earthquakes. These 13 events have occurred with an average repeat time of 600 years since the first post-Mazama event $\sim 7500$ years ago (fig. 1a,b), and the youngest event $\sim 300$ years ago approximately coincides with widespread evidence of coastal subsidence and tsunami inundation in buried marshes along the Cascadia coast. In this paper we further develop the earthquake hypothesis for the origin of Cascadia turbidites, and extend the Holocene turbidite record to $\sim 9850$ years, during which 18 events may correlate along the same region. We also observe that the sequence of Holocene events in Cascadia appears to contain a repeating pattern of events, a tantalizing first look at what may be the long-term behavior of a major fault system.

On the Northern California margin, we collected two piston cores and one box core from Noyo Channel, draining the Northern California continental margin adjacent to the San Andreas Fault. Like Cascadia, these cores show a cyclic record of turbidite beds that may represent Holocene earthquakes on the northern segment of the San Andreas Fault. Here we present 


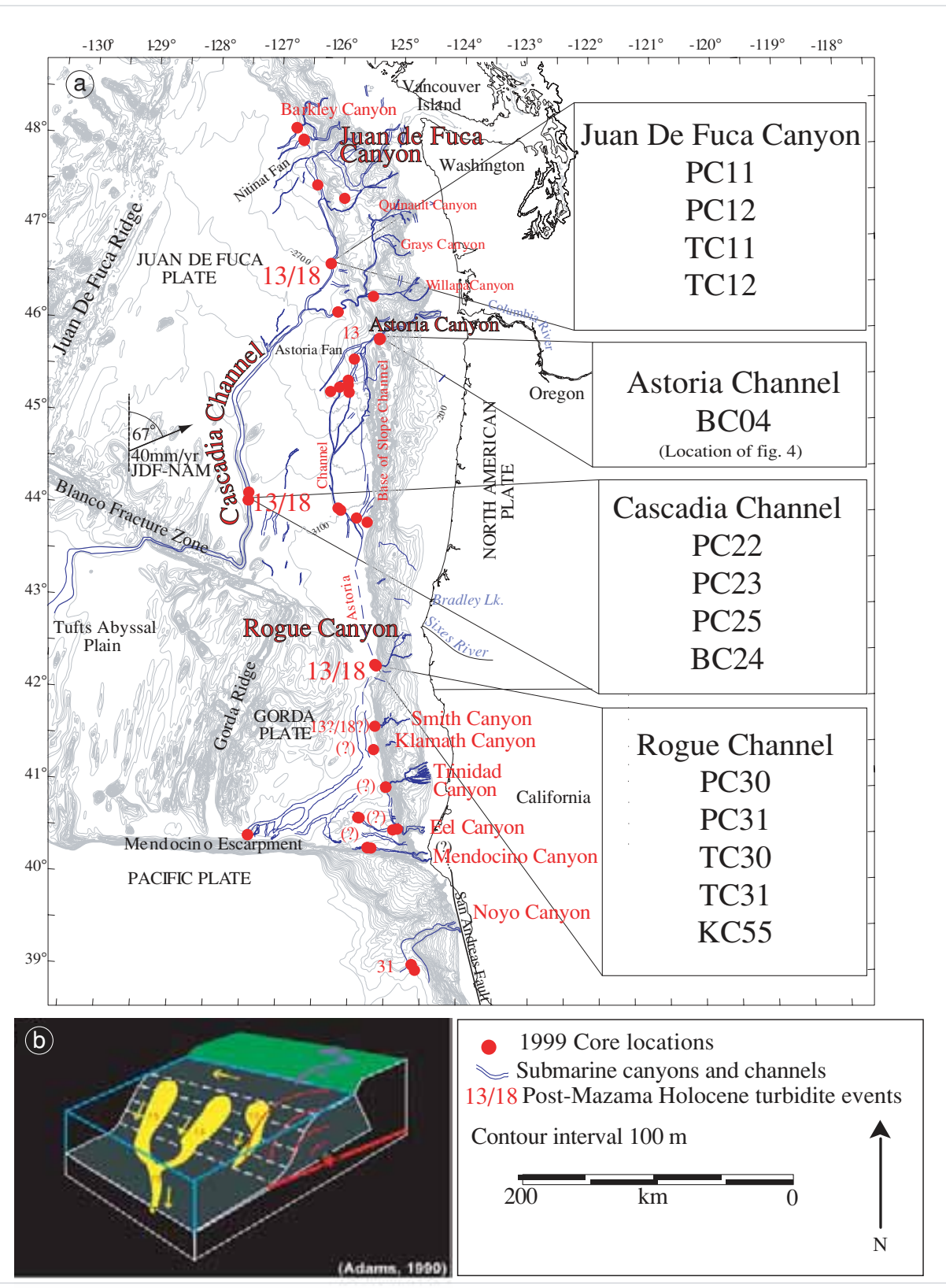

Fig. 1a,b. a) Cascadia margin turbidite canyons, channels and 1999 core locations. Major canyon systems and the number of post-Mazama and/or Holocene turbidites are shown in red. Mazama ash was not present in Barkley Canyon cores or in the cores south of Rogue Canyon. Area of fig. 4 shown by box at Astoria Canyon. b) Synchronicity test at a channel confluence as applied where Washington channels merge into the Cascadia Deep Sea Channel. The number of events downstream should be the sum of events in the tributaries, unless the turbidity currents were triggered simultaneously, as by an earthquake. 
new evidence that these turbidites may represent an earthquake record of the Northern San Andreas system. In total, thirty-one turbidite beds are found above the Holocene/Pleistocene $(\sim 9 \mathrm{ka})$ boundary yielding an average recurrence time of $\sim 300$ years. The ages of the youngest five Northern San Andreas events are in reasonably good agreement with onshore paleoseismic event ages and repeat times. While we presently cannot unequivocally demonstrate that these deposits are earthquake generated, the age similarities and similar number of onshore and offshore events suggests this origin.

\section{Cascadia paleoseismic history}

The past occurrence of great earthquakes in Cascadia is now well established in Cascadia coastal marsh stratigraphy (e.g. Nelson A.R. et al., 1995; Atwater and Hemphill-Haley, 1997; Clague, 1997; Kelsey et al., 2002), and tsunami records in Japan (Satake et al., 1996). More recently, the turbidite event record is being investigated as a long-term proxy for Holocene great earthquakes (Nelson et al., 2003). Consequently, attention has turned to magnitude, recurrence intervals, and segmentation of the margin. Segmented and whole margin ruptures should leave distinctly different stratigraphic records in both the coastal marshes and the offshore turbidite record, however the difficulties of precisely dating stratigraphic evidence of past earthquakes makes unraveling the paleoearthquake record a challenging problem.

\section{The coastal record}

Paleoseismic evidence on land is found in the form of subsided marsh surfaces and tsunami runup or washover deposits of thin marine sand layers with diatoms that are interbedded within estuarine or lake muds (Atwater, 1987, 1992; Darienzo and Peterson, 1990; Atwater et al., 1995; Hemphill-Haley, 1995; Nelson et al., 1995; Hutchinson et al., 2000; Kelsey et al., 2002; Nelson et al., 2000). The tsunami deposits are found several kilometers inland from the coast, up river estuaries, or in low-lying freshwater lakes near sea level, but above the reach of storm surges. A 3500-year record of such tsunami events is encountered in Willapa Bay, Washington (Atwater and Hemphill-Haley, 1997). A 7300-year record is under investigation in Bradley Lake, Oregon (Nelson et al., 2000; Ollerhead et al., 2001). A 5500-year record is also being studied in Sixes River estuary (Kelsey et al., 1998, 2002). Time variance for recurrence intervals of the Willapa Bay tsunami events is as much as 990 years or as little as 140 years between events (Atwater and Hemphill-Haley, 1997). A total of 17 tsunami events have been recognized in the Bradley Lake sediments, where the maximum (900 years) and minimum (100 years) time variance are similar to that found in Willapa Bay (Hemphill-Haley et al., 2000). The Bradley Lake tsunami events are presumed to be local and not distant tsunami on the basis of the height requirement to wash over the spit that separates the lake from the sea. The Sixes River record of 11 events in 5500 years is found 110 $\mathrm{km}$ south of Bradley Lake, and also exhibits a wide variance in time between subduction zone earthquake events from 70 years to 900 years (Kelsey et al., 1998, 2002). In addition to the similar range in time variance between recurrence of events $(\sim 100$ to $\sim 1000$ years $)$ in these long-term coastal records, the average recurrence interval is similar for the Willapa and Sixes River estuaries (500-540 years) and slightly less for Bradley Lake (440 years) (Kelsey et al., 1998, 2002; Nelson et al., 2000). Kelsey et al. (1998, 2002) find that the Willapa and Sixes estuary paleoseismic events are comparable for 2400 to 3500 years BP, differ between 2400 to 800 years BP, and both include the 1700 A.D. event (Jacoby et al., 1997; Yamaguchi et al., 1997). The records of repeated subsidence and tsunami inundation followed by emergence are most likely paleoseismic events because multiple soils buried by estuary muds show evidence of rapid subsidence, followed immediately by incursion of tsunami sands with marine diatoms over the wetland soil surface. Some are associated with liquefaction features (Atwater and Hemphill-Haley, 1997; Kelsey et al., 1998, 2002). The Bradley Lake record is based only on tsunami deposited sands, exhibits a relatively greater number of events per 
unit time than the estuary records, and has 12 events requiring a tsunami inundation of $>5.5 \mathrm{~m}$.

The most abundant high precision age data are available for the most recent subsidence event, which probably occurred within a few decades of 1700 A.D. 300 years ago. Dendrochronology of western red cedar in Washington and other Northern Oregon estuaries show tree death occurred between August, 1699 and May 1700 (Jacoby et al., 1997; Yamaguchi et al., 1997), and was most likely due to salt water incursion due to subsidence. The age of this event is supported by evidence of a far-field tsunami in Japan on January 26, 1700 A.D., which has been attributed to a subduction earthquake on the Cascadia subduction zone (Satake et al., 1996). The $~ 300$ year event is widespread, with evidence found from Northern California to Vancouver Island (Clague, 1997). For older events, error bars for numerical ages are significantly larger and the difficulty in identifying anomalous local subsidence events increases. The land record of submergence, tree death, and tsunami, as well as the turbidite record offshore all require correlation along strike to determine whether events represent whole margin or segmented rupture. In the case of the land record, earthquake origin has been quite well established, but correlation remains elusive. Conversely, with the offshore record, the consistency of the records and several key tests of synchronicity demonstrates a probable consistent correlation, while demonstrating earthquake origin is more difficult.

\section{Turbidite correlation and dating methods}

The use of turbidite deposits as paleoearthquake proxies is, like other forms of paleoseismology, dependant on as complete as possible an understanding of the depositional environment, physiography, and dynamics of emplacement of the stratigraphic record. In this section, we outline some of the methods we and others are developing to test the viability of this proxy record.

Channel pathway analysis - Turbidity currents result from channel wall slumps, mostly of unconsolidated material, in the upper reaches of canyons. Large slumps of older blocky material into a channel may attenuate or deflect turbidity currents that might otherwise travel to core sites on the abyssal plain. We analyze the thalweg profiles of the channel systems, along with the swath bathymetry along the channel walls to search for such slumps that may have blocked or diverted turbid flows, thus biasing the stratigraphic record downstream (fig. 2). Another possible influence is folding and faulting. Griggs and Kulm (1970) showed that major turbidity currents are up to $100 \mathrm{~m}$ high and 17 $\mathrm{km}$ wide in Cascadia Basin. Thus faulting and folding at reasonable slip rates, and even moderate slumping are perhaps unlikely sources of disruption of channel flow, though large slides and faults with high slip rates might be capable of biasing the downstream record.

Core siting - In our Cascadia work, we found that surface morphology in the channels was a critical factor in choosing exact sample

Axial gradient profile for base of Slope Channel
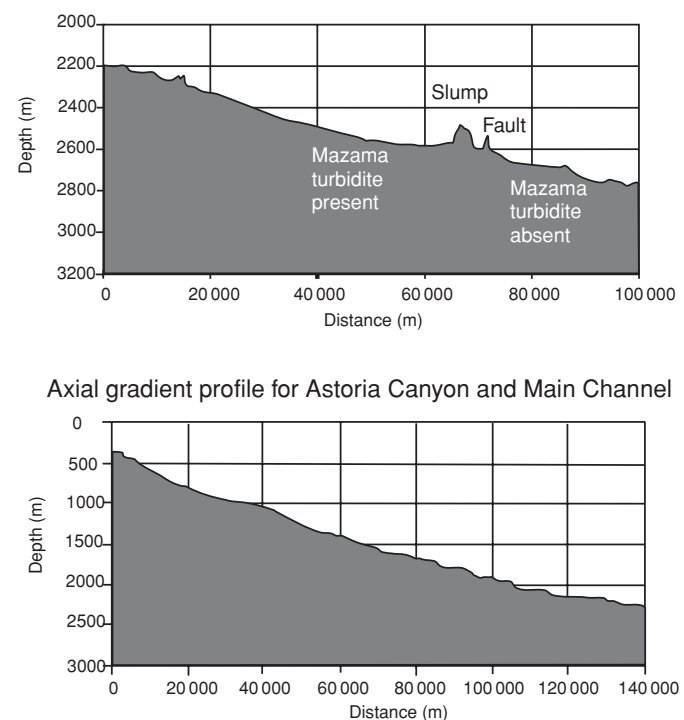

Fig. 2. Example of channel blocking by a large submarine slide along one part of the Astoria fan system. This channel lies along the base of the continental slope. 
location. In a gross sense, distance from the source and distance from the channel thalweg controls grain size. In detail, we found that the turbidite record was very robust and best preserved in thalwegs, on point bars, in the lee of point bars, and on low terraces above the thalweg. In general, we try to sample each system both down channel, and across major channels in order to capture a complete event record and test for sensitivity in both directions. The quality of the record, and our ability to capture the Holocene interval was, however, sensitive to local conditions. After some trial and error we found that sampling in the lee of point bars was a good strategy in proximal locations (fig. 3). These locations included the complete record, did not include very coarse material, and tended to have a somewhat expanded record, which increases dating precision by reducing the sample interval needed to get enough forams for ${ }^{14} \mathrm{C}$ dating. In more distal localities, we sampled local sediment pools to find an expanded record in areas that otherwise had lower than optimal sedimentation rates. In any given setting some trial and error is required to choose sites that offer optimal conditions, an expanded record,

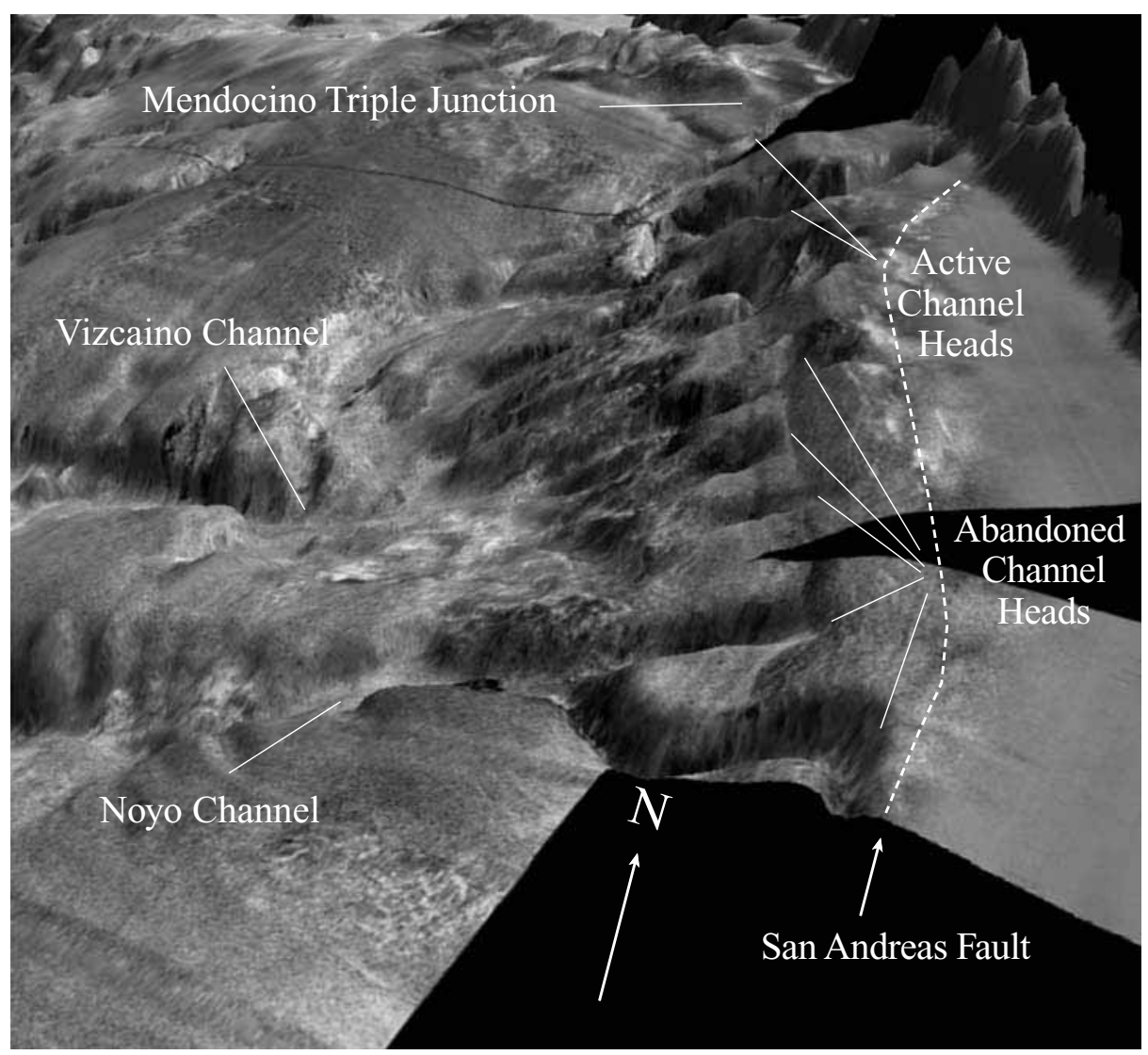

Fig. 3. GLORIA sidescan image overlaid on SeaBeam bathymetry showing the truncation of channel heads of Noyo and Vizcaino channels (dashed line) and the active channels of the Delgada Fan, Northern California margin. The $90^{\circ}$ bend in the head of Noyo Canyon at the bottom of the image (just above the $\mathrm{N}$ on the north arrow) has been controlled by the SAF. Abandoned channels appear to result from dextral SAF motion. Location shown on fig. 9. Fault location from Castillo and Ellsworth (1993) and interpretation in this study. 


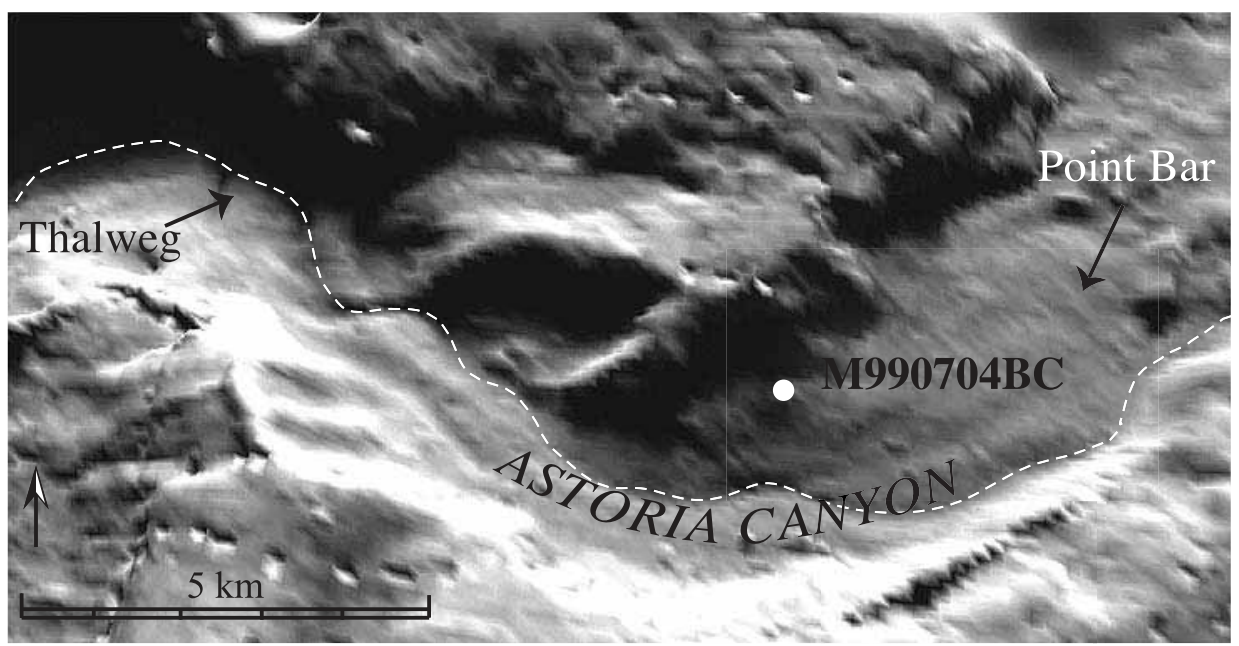

Fig. 4. $100 \mathrm{~m}$ resolution shaded swath bathymetry of a portion of Astoria Canyon, Northern Oregon. The siting of turbidite cores at sea is facilitated by using $3 \mathrm{D}$ visualization of the canyon/channel morphology. To obtain the most complete turbidite record we avoid erosive channel thalwegs and coarse grained frontal point bars. We found non-erosive complete records in the lee of point bars, such as this site for core M9907-04BC.

and a Holocene section that can be cored with existing gear. Backscatter data, where available, were used together with bathymetric data to reveal depositional patterns, relative grain size distribution, and to determine the most active channels (fig. 4).

Age Control - AMS ${ }^{14} \mathrm{C}$ ages are determined from planktonic forams deposited in the hemipelagic sediments that underlie each turbidite sequence. Benthic forams could be reworked, as could previously deposited planktonic forams entrained in the turbidite deposit, thus care is taken to select only hemipelagic planktonic forams. Benthic forams may be unreliable and give erratic ages, possibly due to the unknown deep-water reservoir correction (M. Kashgarian, Lawrence Livermore Lab., 2000). Our foram assemblages were dominated by Turborotalia pachyderma (sinistral and dextral) and Globigerina bulloides, but used all ( 20) planktonic species in most cases (D. Boettcher, MicroPaleo Associates, written report, 2003). Previous work has shown that in mid to distal parts of the Cascadia Channel systems, there is little evidence of erosive turbidite em- placement, thus sampling in the hemipelagic interval immediately below the coarse turbidite base is used to date events. Our rationale is to collect samples from the youngest hemipelagic interval between events to date the overlying event. Though there may be some erosion of this interval, thus biasing events to slightly older ages, we use more distal cores, which are less likely to have basal erosion for primary dating, and inspect the bases visually for evidence of erosion. Although bioturbation blurs the age of the surface $10 \mathrm{~cm}$ or so, there is some evidence that large grains such as forams are not moved vertically within the sediment as much as the sediment is bioturbated, reducing this problem somewhat (Thomson and Weaver, 1994). The cores are examined for organic matter and mica, which is characteristic of turbidite tails in this area, and samples are taken once the upper and lower limits of the turbidites are found. The hemipelagic fraction is also distinguished by greater bioturbation (e.g. Nelson, 1968; Griggs et al., 1969).

Because planktonic forams can be reworked when they are entrained in the turbidite deposit, 
we sieve the $>0.062 \mathrm{~mm}$ sand fraction and carefully hand-pick planktonic forams only from the minimum interval needed to acquire enough forams $(1-4 \mathrm{~cm})$ of hemipelagic sediment below the base of the turbidite and above any underlying turbidite tail. Raw AMS radiocarbon ages are reservoir corrected and converted to calendar years (cal years) by the method of Stuvier and Braziunas (1993). Though there may be a time-varying surface reservoir age (Southon et al., 1990), this has not yet been demonstrated. In Cascadia Channel, our AMS intercept age for the youngest event is 304 years BP, for the known 1700 Cascadia event. Additionally, the first post-Mazama turbidite event also is within $\sim 150$ years of the most current Mt. Mazama eruption age (7627 \pm \pm 150 ; Zdanowicz et al., 1999). Both these ages indicate the reservoir corrections are approximately correct.

Event correlation and recurrence intervals We address the mean interval between turbidite events and variability of this mean by two semiindependent methods: 1) directly dating the events, and 2) detailed analysis of the hemipelagic sediment interval between turbidite events in selected new cores. This requires detailed analysis of coarse fraction constituents to separate the turbidite tail muds from the inception of the hemipelagic sediment. We analyzed all cores using the OSU Geotech MST system, collecting gamma (GRAPE) density, $P$-wave velocity and magnetic susceptibility series for each core. In order to establish a complete chronology at a given site, correlation between the piston and trigger cores, box cores, and sometimes multiple cores at the same site is needed. This is because the tops of cores are sometimes lost (most common with piston cores), and separation of core segments may also occur in the piston core. Correlation between multiple cores aided by the MST data is essential in these cases. We also utilize $\mathrm{x}$-radiographs to image details of the individual turbidites, search for multiple coarse pulses, or multiple events, and identify the top of the turbidite tails. The $\mathrm{x}$-radiographs are proving invaluable, particularly in the San Andreas cores where multiple pulses are common.

\section{The Cascadia turbidite record}

Concurrent with the discovery of the first buried marsh sequences on land, Adams (1985, 1990) assessed the possibility that turbidites in channels of Cascadia Basin contained a record of great earthquakes along the Cascadia margin. He examined core logs for the Cascadia Basin channels, and determined that many of them had between 13 and 19 turbidites overlying the Mazama ash datum. In particular, he found that three cores along the length of Cascadia channel contain 13 turbidites and argued that these 13 turbidites correlate along the channel (as did Griggs and Kulm, 1970). Adams observed that cores from Juan de Fuca Canyon, and below the confluence of Willapa, Grays, and Quinault canyons, contain 14-16 turbidites above the Mazama ash. The correlative turbidites in Cascadia Channel lie downstream of the confluence of these channels. If these events had been independently triggered events with more than a few hours separation in time, the channels below the confluence should contain from 26-31 turbidites, not 13 as observed. The importance of this simple observation is that it demonstrates synchronous triggering of turbidite events in channel tributaries, the headwaters of which are separated by $50-150 \mathrm{~km}$. Similar inferences about regionally triggered synchronous turbidites in separate channels are reported in Pilkey (1988). The extra turbidites in the upstream channels may be the result of smaller events. This synchronicity test is a powerful relative dating technique that is completely independent of radiocarbon dating, which rarely has the precision to correlate events.

In July, 1999, we collected 44 (4" diam.) piston cores, 44 companion trigger cores (also $4^{\prime \prime}$ ) and eight $30 \mathrm{~cm}$ box cores in every major canyon/channel system from the northern limit of the Cascadia subduction zone near the Nootka Fault, to Cape Mendocino at its southern terminus (fig. 1a; Goldfinger and Nelson, 1999; Nelson and Goldfinger, 1999; Goldfinger et al., 2003). Cores were run through the MST scanner as whole rounds to collect density, velocity, and magnetic susceptibility data, then split, photographed and described on board. 


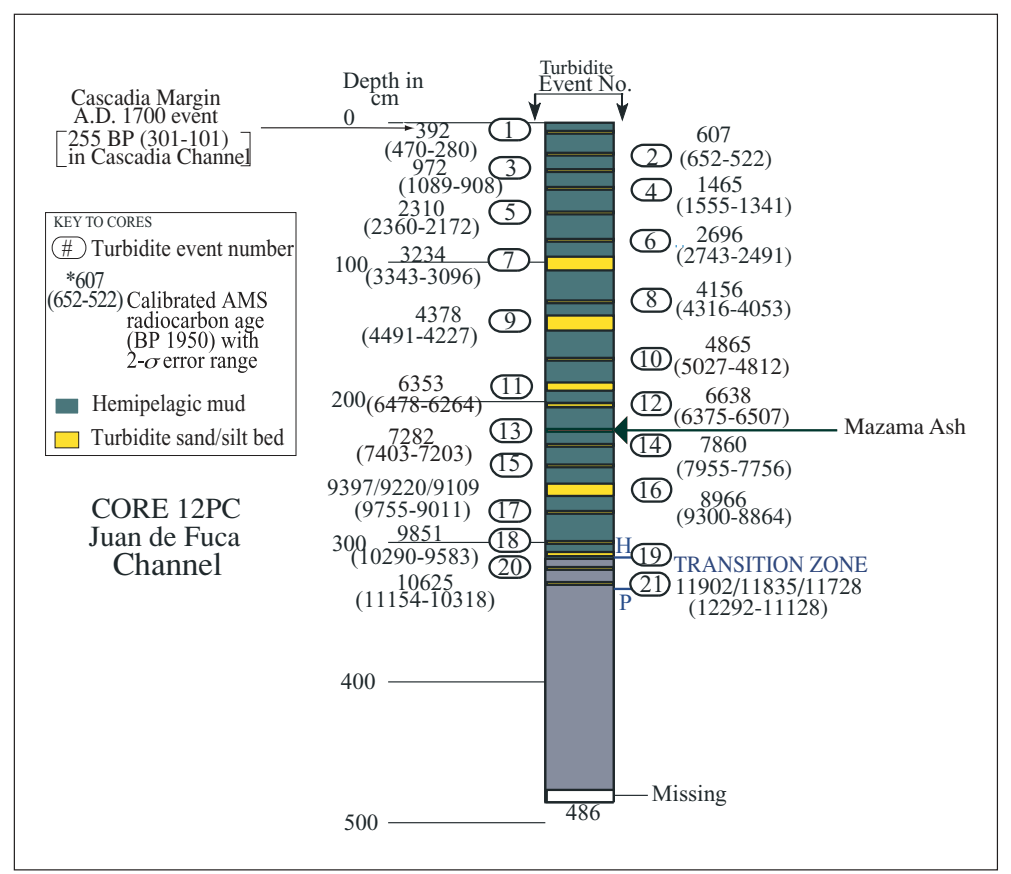

Fig. 5. Schematic core diagram for piston core M9907-12PC from Juan de Fuca Channel. Calibrated radiocarbon ages are shown with $2 \sigma$ error ranges. AMS ages are obtained from planktonic forams in the hemipelagic mud beneath events. Recurrence intervals between events are calculated and plotted in fig. 8. Location shown on fig. 1a.

We find that thirteen post-Mazama events are found along $600 \mathrm{~km}$ of the margin in the Cascadia, Willapa, Grays, Astoria, Juan de Fuca, and Rogue Canyon/Channel systems (figs. 1 and 5 to 7; Nelson et al., 2003). Though the Holocene-Pleistocene boundary is a bit less certain as a datum, these same channels also have 18 post-datum events, extending this record to 10000 years. In previously existing cores, we found only 3 post-Mazama events in middle and lower Astoria Channel, which appeared to contradict Adams (1990) hypothesis for 13 events. In 1999 cores, we find a progressive loss of turbidites from 13 to 10 to 7 to 6 to 5 events at each successive downstream channel splay in the distributary upper Astoria Fan. This down-channel loss of events resulting in only 3 events in the mid-lower Astoria Channel explains the previous contradiction, and shows that the post-Mazama turbidite record is consistent along the margin.

\section{Mechanisms for triggering of turbid flows}

Adams (1990) made a convincing case for synchroneity of Cascadia margin events. But are these events all triggered by earthquakes? Adams suggested four plausible mechanisms for turbid flow generation: 1) storm wave loading; 2) great earthquakes; 3) tsunamis, and 4) sediment loading. To these we add 5) nearby crustal earthquakes, 6) in-slab earthquakes, 7) aseismic accretionary wedge slip, 8) hyperpycnal flow, and 9) gas hydrate destabilization. All of these mechanisms may trigger individual submarine slides and or turbid flow events, but how can earthquake-triggered events be distinguished from other events? Investigators have attempted to distinguish seismically generated turbidites from storm, tsunami, and other deposits. Nakajima and Kanai (2000) and Shiki et al. (2000) argue that seismo-turbidites can in some cases be distinguished sedimentolog- 


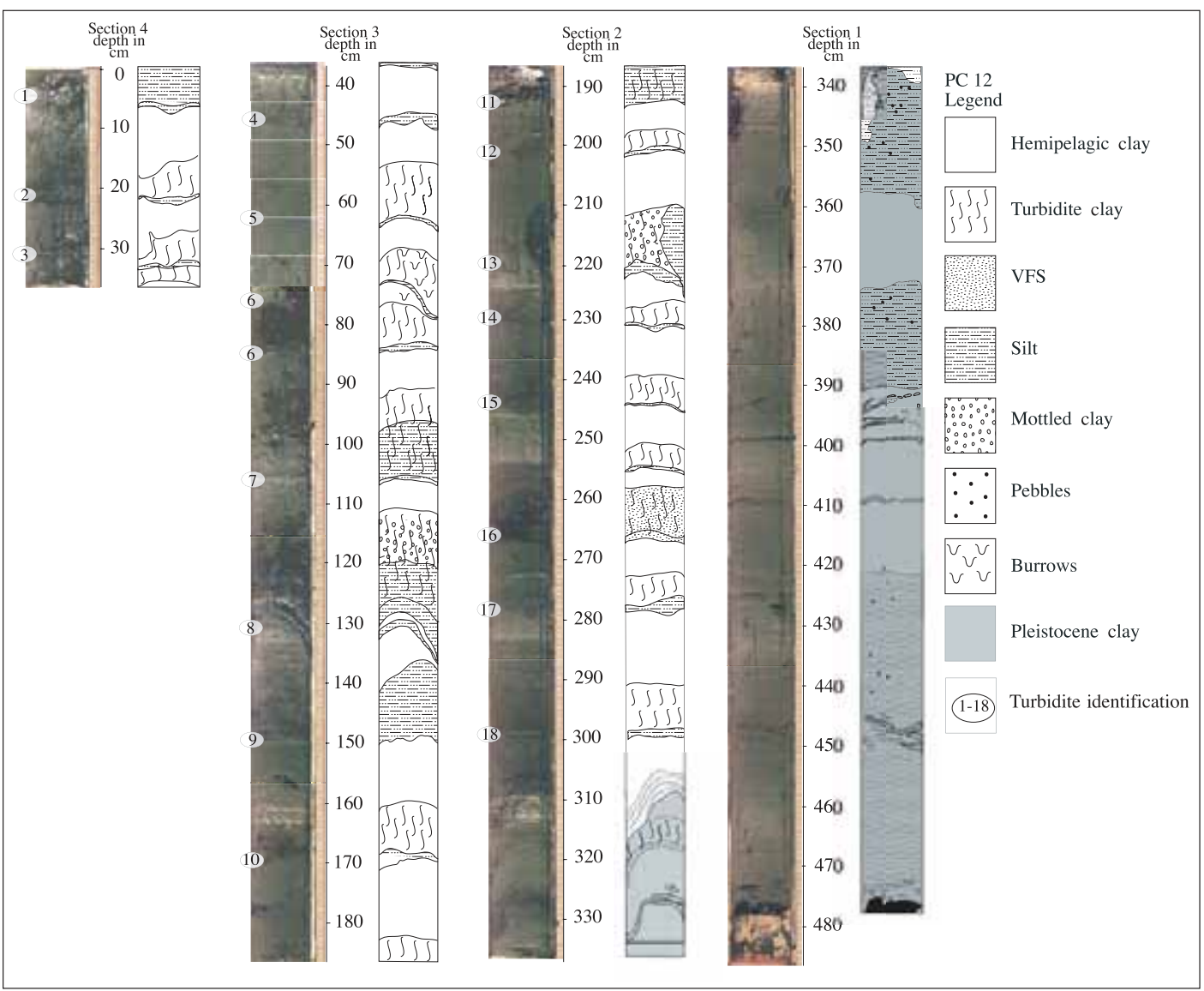

Fig. 6. Summary core logs and digital photographs of all sections of Juan de Fuca core M9907-12PC. Turbidites shown as «T» followed by numerals. See fig. 1a for location.

ically. They observe that known seismically derived turbidites in the Japan Sea and Lake Biwa are distinguished by wide areal extent, multiple coarse fraction pulses and variable provenance (from multiple or line sources), and greater depositional volume than storm-generated events. These investigators observe that known seismo-turbidites caused multiple slump events in many parts of a canyon system, generating multiple pulses in an amalgamated turbidity current, some of which sampled different lithologies that are separable in the turbidite deposit. In the Japan Sea, the stacked deposits are deposited in order of travel time to their lithologic sources, demonstrating synchronous triggering of multiple parts of the canyon system. These turbidites are also complex, with reverse grading, cutouts, and multiple pulses. Gorsline et al. (2000) make similar observations regarding areal extent and volume for the Santa Monica and Alfonso Basins of the California borderland and Gulf of California respectively. In general, these investigators observe that known storm sediment surges are thinner, finer grained and have simple normally graded Bouma sequences. We observe that many, but not all, of the turbidite sequences in Cascadia are similar to the historically known 
seismic turbidites reported by Nakajima and Kanai (2000; their fig. 3).

While there may yet be applicable global, regional or local criteria to distinguish between turbidite triggers, these are at present poorly developed. Thus far in Cascadia, we have not attempted to distinguish between triggering mechanisms with sedimentological criteria, but have used the spatial and temporal pattern of event correlations and Adams' synchronicity test at the confluence of Willapa, Juan de Fuca, and Cascadia channels to establish a regional correlation that cannot be the result of triggers other than earthquakes. We confirm Adams' results from the channel confluence of 13 postMazama events both above and below the confluence. Because turbidity currents deposit their loads in a matter of hours, they are excellent relative dating horizons, the relative age resolution provided by this feature of turbidites is far greater than any radiometric or other absolute technique. The synchronicity of event records established at the confluence effectively eliminates non-earthquake triggers because other possible mechanisms are extremely unlikely to trigger slides in separate canyons only a few hours apart. This would have to have take place 13 consecutive times to produce the core record we observe. The correlation is strengthened by extending the record to 18 Holocene events at all sites between the Smith River and Juan de Fuca Canyon. While this does not have the same power as the confluence test, the similarity is striking, and very unlikely to have oc-

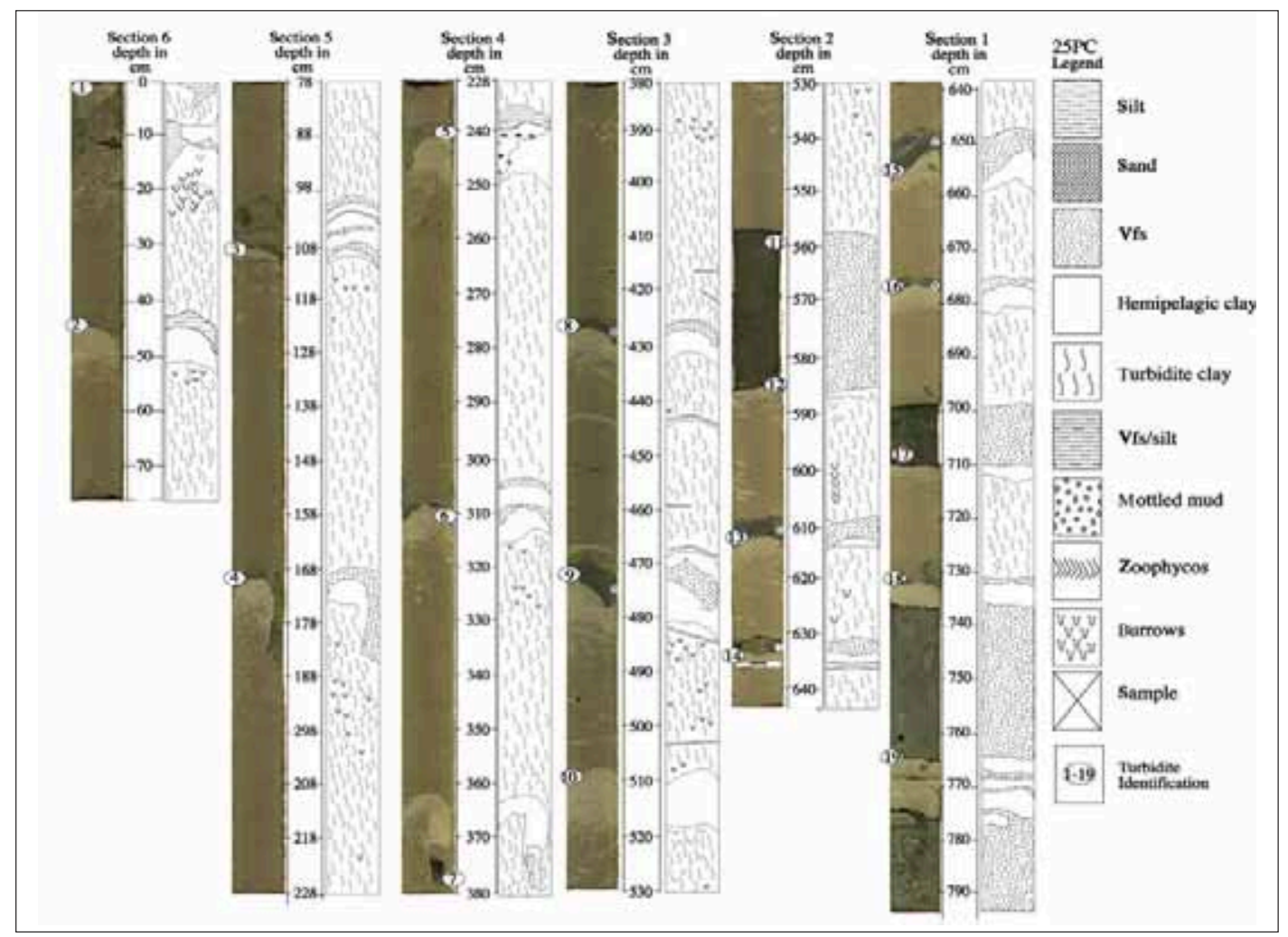

Fig. 7. Summary core logs and digital photographs of all sections of Cascadia Channel core M9907-25PC. See fig. 1a for location. 
curred without a regional earthquake trigger. An alternative explanation could be a series of earthquakes that took place within hours of each other along the length of the margin. While possible, the precision of the relative dating provided by the time of settling of turbid flows restricts this to only a few hours time for Central Washington. Additionally, whatever sequence of events occurred, it would also have to take place in such a way that the stratigraphic record yields 18 events in all locations. Again this is not impossible, but far less likely than the simplest explanation, that of 18 plate wide events. We are presently exploring other correlation techniques that may enable direct linkage of the Rogue and either Cascadia or Rogue records, which do not have a confluence, and thus are not positively correlated.

We can make some additional observations about the applicability of other triggers that might be expected to generate turbid flows. Storm wave loading is a reasonable mechanism for triggering of turbid flows, but is an unlikely trigger in Cascadia. On the Oregon and Washington margins, although deep-water storm waves are large, the canyon heads where sediment accumulation occurs are at water depths of 150-400 $\mathrm{m}$. These depths are at or below the maximum possible for disturbance by storms with historical maximum significant wave heights of $\sim 20 \mathrm{~m}$, though rare mega storms cannot be ruled out. Tsunamis may also act as a regional trigger, however the 1964 Alaska $M_{w} 9.0$ event did not trigger a turbidite observed in any of the cores, although it did serious damage along the Pacific coast (Adams, 1990). Crustal or slab earthquakes could also trigger turbidites. To investigate this possibility, we resampled the location of a 1986 box core in Mendocino Channel, where the uppermost event is suspected to be the 1906 San Andreas event. Since 1986, the $M_{w} 7.2$ Petrolia earthquake occurred in 1992, either on the plate interface or lowermost accretionary wedge landward of this site (Oppenheimer et al., 1993). Despite the epicentral distance of only a few kilometers from the canyon head, we were surprised to find no surface sand in the 1999 box core, nor was it present at other Southern Cascadia Channel locations. At least for this event, an $M_{w} 7.2$ earth- quake was not sufficient to trigger a turbid flow, or alternatively, insufficient sediment was present. Conversely, the $M_{w}=6.9$ Loma Prieta earthquake apparently did trigger some type of turbid flow in Monterey Canyon at a much greater epicentral distance (Garfield et al., 1994).

The remarkable similarity of turbidite records in channels systems monitoring the northern $2 / 3$ of the Cascadia margin suggests strongly that at least this part of Cascadia has experienced 13 post-Mazama events, and 18 Holocene events (fig. 1a,b). These events were sufficiently large to both generate turbidites, and to correlate along the length of the margin. Further correlation is presently underway using radiocarbon dating, but will face difficulties with the accumulated errors and uncertainties. Nevertheless, the circumstantial case presented by Adams (1990) is now considerably stronger.

South of the Rogue Canyon, the turbidite event frequency for the Northern Gorda plate region may also contain 18 events in Smith and Klamath canyons. The Northern California channels contain no Mazama ash, and have a more diffuse Holocene/Pleistocene faunal boundary, thus correlation will depend heavily on radiocarbon dates. For the Southern Gorda area the events are much more frequent. AMS ages for events in the Southern Gorda region indicate average turbidite recurrence intervals of 133,75 , and 34 years respectively for the Trinidad, Eel, and Mendocino channels, increasing progressively toward the Mendocino triple junction. The number of possible earthquake sources for triggers also increases progressively toward the triple junction, and includes the Mendocino and Blanco faults, internal Gorda plate faults, and perhaps the Northern San Andreas. The potential for sedimentological triggering is also higher, with the Eel, Trinidad, and Mendocino Canyon heads very close to the coast, increasing the likelihood of hyperpycnal flow input. Three earthquakes of magnitude 6.9 to 7.4 have occurred in the past 21 years in the triple junction area. However, we estimate that the $10-14 \mathrm{~cm}$ of hemipelagic sediment at the surface in Mendocino Channel represents 50 to 70 of deposition, thus these three earthquakes have 
not triggered turbid flow events in Mendocino Channel.

Unlike the other Cascadia systems, both Eel and Mendocino canyon heads erode close to the shoreline where the canyon heads may intersect littoral drift sediment that can be funneled downcanyon by storms. Given the probable mix of interplate, intraplate, and sedimentological (nonearthquake) events in the Southern Gorda region, we are as yet unable to make detailed inferences about the earthquake record in this area.

\section{Turbidite recurrence interval data}

We have plotted the turbidite event age versus recurrence interval for the individual event pairs available as of this writing (fig. 8). The plot includes the best of our «key» cores thus far, M9907-12PC from Juan De Fuca Canyon (figs. 5 and 6). This is the first of our cores to have all Holocene turbidite events dated, with several latest Pleistocene events included, up to event T21 (T19 is not included due to age rever-

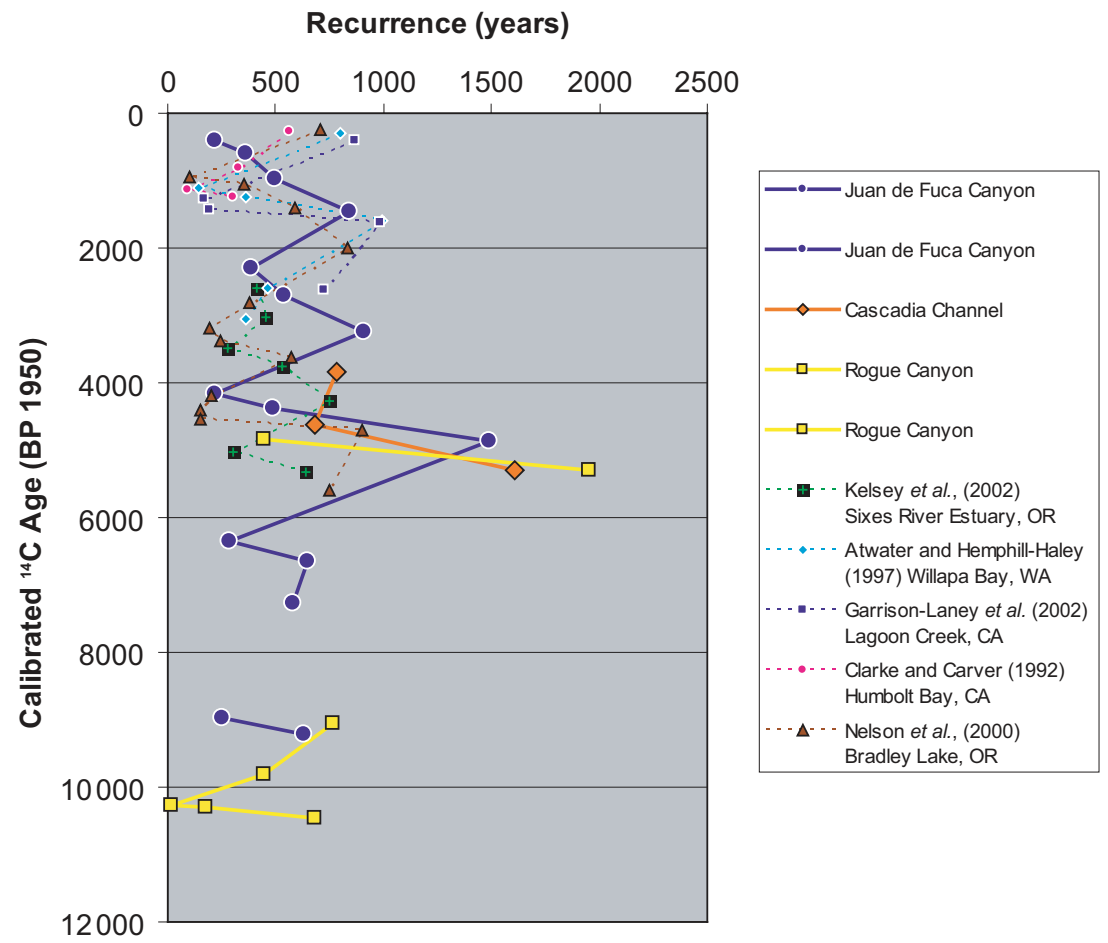

Fig. 8. Summary plot of offshore and onshore calibrated ${ }^{14} \mathrm{C}$ Ages and individual recurrence intervals. Partial results from the turbidite record based on available radiocarbon ages. Multiple plots are shown where series in Juan de Fuca and Rogue channels is broken by a bad or missing date. Where three key sites are dated, note good correlation between Juan de Fuca Canyon, Cascadia Channel, and Rogue Canyon at 4000-6000 years BP. Note good agreement between Juan de Fuca Canyon and onshore records at 0-6000 years BP. «Extra» events in Southern Oregon are indicated in the 3000-4000 BP range (also noted by Kelsey et al., 2002). For turbidite dates, intercept ages are plotted at the upper bound of each interval. Offshore turbidite data shown as solid lines, dashed lines show land data cited in legend. The pattern of events contains age offsets, both between land and offshore data, and among the offshore cores. These are almost certainly due to spatial and temporal variations in water mass «age» during the Holocene, which is corrected here using the fixed values of Stuvier and Braziunas (1993). Resolution of time and space variant «reservoir corrections» is a work in progress. 
sal for that event). The plot also includes partial records for the Cascadia and the Rogue systems, for which complete AMS age results are not yet available. The recurrence period versus time plot has some strengths, the principal one being that comparing cores uses the pattern of recurrence rather than the raw ages, which have not been corrected for sedimentation rate, possible basal erosion, and tuning of the ${ }^{14} \mathrm{C}$ reservoir correction. Each interval is arbitrarily plotted at the younger event age that delimits the interval. Where an event is defined by multiple ages due to multiple intercepts on the ${ }^{14} \mathrm{C}$ calibration curve, we use the median age if there is no statistical preference.

The average post-Mazama recurrence time based on the Juan de Fuca core is $\sim 581$ years, with the shortest interval being 222 years (T8T9), the longest 1488 years (T10-T11). The average post-Mazama recurrence interval using an age for T13 averaged from all channels is $\sim 600$ years. The mean recurrence time based on all available intervals is $\sim 564$ years, which is the Holocene average for 18 events terminated by the A.D. 1700 event that occurred 250 years before the 1950 reporting standard for calibrated radiocarbon ages (9841-250/17). This average is based on the average of three AMS ages for event T18 from our key cores in Juan de Fuca, Rogue, and Cascadia channels. These ages are 9849 (10287-9784), 9851 (10290-9583), and 9824 (10274-9540) for Cascadia, Juan de Fuca, and Rogue channels respectively.

With a single complete, but uncorrected record, the patterns may (or may not) be robust, but there does seem to be a repeating pattern of a long interval ending in an earthquake, followed by a moderately long interval, then 1 or 2 shorter intervals. Over the last $\sim 7500$ years, the pattern appears to have repeated three times, with the most recent A.D. 1700 event being the third of three events following a long interval of 845 years between events T4 and T5. This long interval is one that is also recognized in many of the coastal records, and may serve as an anchor point between the offshore and onshore records. The partial Rogue and Cascadia records show a possible pattern correlation with the complete Juan De Fuca record for the overlapping events.
While it is temping to expound about earthquake clustering and long-term fault behavior, we emphasize here that the analysis shown in fig. 8 is incomplete, and confirmation of this pattern will require age data from the other key cores that is not yet available. We are encouraged that despite occasional reversed ages and other problems inherent in paleoseismology, the extensive turbidite event record in Cascadia Basin will overcome these problems and using pattern matching and correlation, will provide a robust long-term paleoseismic history.

\section{Preliminary investigation of turbidite se- quences along the Northern California margin}

Following on the successful Cascadia effort, we are beginning an investigation of the Holocene rupture history of the Northern San Andreas Fault using similar methods. The plan includes collection of a spatially extensive set of new piston cores in channel systems draining the adjacent continental margin from south of San Francisco to the Mendocino Triple Junction. This work will utilize a number of «Key» cores to develop the Holocene event record in all channel systems draining Northern California. Fortunately, we already have one of these «Key» cores, M9907-49PC, collected in 1999 as part of the Cascadia project as a control core in Noyo Channel (figs. 9 to12). We are presently using this piston core and a companion box core to develop an event history for the northern end of the San Andreas system.

The physiography of the margin is ideal for this investigation. The Northern San Andreas fault has a single main fault strand (Castillo and Ellsworth, 1993), and few other regional or local seismic triggers are available. The margin channels are numerous, and offer excellent spatial sampling of the Holocene record along this important fault system. The Northern San Andreas offers an excellent opportunity to investigate the long-term history of a relatively simple fault system, and relate that history to the current controversy over characteristic versus stress triggering models of earthquake behavior. 


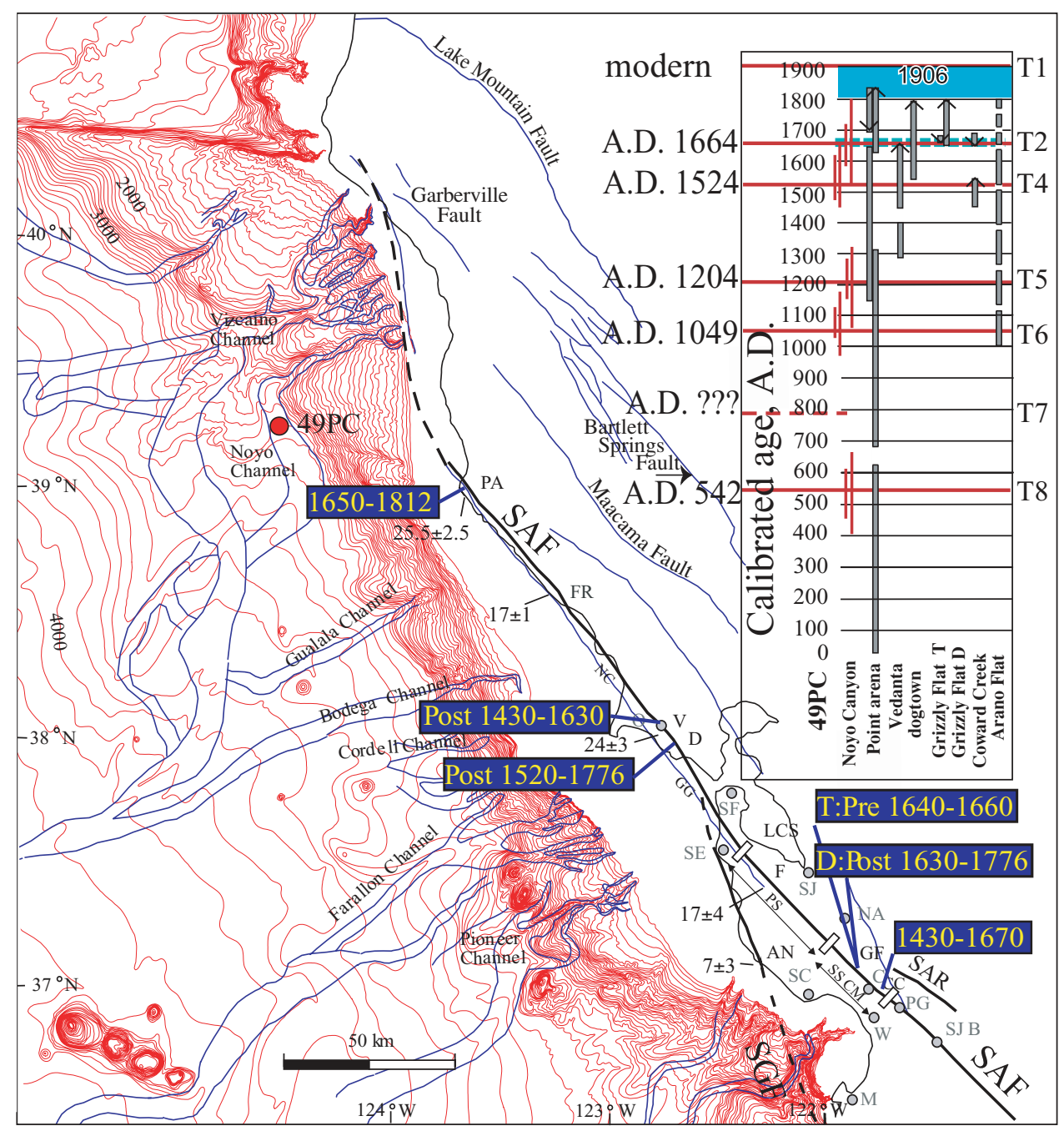

Fig. 9. Map showing channel systems, onshore major faults, and location of 1999 core M9907-49PC on Noyo Channel. Summary of land paleoseismic data along the San Andreas is also shown. Inset shows age constraints for recent events reported at land sites with turbidite event data (T-values and horizontal lines - due to basal erosion, T3 cannot be dated). Horizontal dashed band in mid 1600's is the estimated age of the penultimate event from trenching (T) and dendrochronology (D) at Grizzly Flat. Grey vertical bars in inset show the $2 \sigma$ age ranges of radiocarbon dates used to constrain the age of onshore recent events. Up arrows indicate the event post-dates the age range, down arrows indicate the event pre-dates the age range. Red vertical bars on turbidite events represent the one and two sigma range for Noyo Canyon ages. Numbers (with errors) and letters locate slip rates and event chronology sites. PA - Point Arena; FR - Fort Ross; V - Vedanta; O - Olema; D - Dogtown; GG - Golden Gate; SF - San Francisco; SE - Seal Cove; LCS - Lower Crystal Springs; F - Filoli; AN - Ano Nuevo; SJ - San Jose; NA - New Almaden; GF - Grizzly Flat; C - Corralitos; CC - Coward Creek; W - Watsonville; PG - Pajaro Gap; SJB - San Jaun Bautista; SC - Santa Cruz; M - Monterey; NC - North Coast segment, containing all segments. (Land data after Schwartz et al. (1998), modified from Niemi and Zhang (2000). Data added at Arano Flat from Fumal et al. (1999)). Offshore channels interpreted from GLORIA sidescan sonar data and offshore bathymetric compilation, this study. 


\section{Northern San Andreas seismotectonic setting}

The San Andreas Fault is probably the bestknown transform system in the world. West of the Sierra Nevada block, three main fault systems accommodate $\sim 75 \%$ of the Pacific-North America plate motion, distributed over a 100 km wide zone (Argus and Gordon, 1991). The remainder is carried by the Eastern California shear zone (Argus and Gordon, 1991; Sauber, 1994). The Northern San Andreas is the main system, accommodating about $25 \mathrm{~mm} / \mathrm{yr}$ of the $\sim 34 \mathrm{~mm} / \mathrm{yr}$ distributed across Western California. Most of the remainder is taken up on the parallel Hayward-Rogers Creek system, and the slightly divergent Calaveras Fault System further to the east. South of San Francisco, the transform system becomes more complex, and includes the offshore San Gregorio Fault, which joins the Northern San Andreas at Olema, just north of San Francisco (fig. 9). Between San Francisco and Cape Mendocino, the main strand of the San Andreas is a relatively simple system with most strain localized on the main strand. Seismicity offshore is virtually nil, with the exception of the Mendocino triple junction region. Since the 1906 rupture, the main San Andreas has been nearly aseismic, with only a few small events near Pt. Arena.

\section{Northern San Andreas onshore paleoseismicity}

The San Andreas system has been intensely studied on land, and has been divided into segments based on its historical record of earthquake behavior. The northern segment ruptured in the $1906 M_{w} 7.8$ earthquake, and rupture extended from the at least San Francisco north to Shelter Cove near Point Delgada (fig. 9). The paleoseismic history of the Northern San Andreas system is presently under investigation using trenching and marsh coring. The $M_{w} 7.8$ earthquake in 1906 clearly ruptured the surface along the San Francisco Peninsula to as far north as Point Arena (Lawson, 1908). Some debate exists regarding the full length of the 1906 rupture. Original investigations of surface rupture are summarized in Lawson (1908), and included a description of surface rupture as far north as Shelter Cove. Much later, McLaughlin et al. $(1979,1983)$ questioned these reports on the basis of bedrock mapping which indicated that the main fault strand had not displaced features dated at $\sim 13000$ years BP. Seismological evidence does not require slip on the San Andreas north of Point Arena, though Thatcher et al. (1997) infers from geodetic data that $\sim 8.6 \mathrm{~m}$ of slip occurred on the fault in the Shelter cove area. Brown (1995) re-examined surface morphology and the original field reports by F.E. Mathes from 1906, and concluded that the original reports of surface rupture were correct, and that many effects of the rupture are still observable today. Most recently, Prentice et al. (1999) also re-examined Mathes' field notes and photographs and trenched along the 1906 rupture. Like Brown (1995), they conclude that abundant evidence for 1906 rupture exists, and estimate a minimum slip-rate of $14 \mathrm{~mm} / \mathrm{yr}$ for the Northern San Andreas based on a $180 \mathrm{~m}$ offset of colluvial deposits dated at $13180 \pm 170 \mathrm{cal}$ years BP. The southern end of the rupture extends as far south as the Santa Cruz mountains (Schwartz et al., 1998), giving a minimum rupture length of $\sim 470 \mathrm{~km}$.

The paleoseismology of the Northern San Andreas has been investigated at Olema, $45 \mathrm{~km}$ north of San Francisco, at Dogtown, close to the Olema site, at Point Arena, and at Grizzly Flats in the Santa Cruz mountains. At the Vendanta site near Olema, Niemi and Hall (1992) found that offset stream channels showed that the fault ruptured along a single main strand, and offset stream deposits dated at $1800 \pm 78$ years by 40 $45 \mathrm{~m}$. The maximum Late Holocene slip rate derived from these data is $24 \pm 3 \mathrm{~mm} / \mathrm{yr}$, in good agreement with geodetic data. They estimate that if the 4-5 m slip event recorded in 1906 were characteristic, the recurrence time for such events would be $221 \pm 40$ years. At Point Arena, $145 \mathrm{~km}$ to the northwest, Prentice (1989) recognized four events that offset a Holocene alluvial fan channel by $64 \pm 2 \mathrm{~m}$. The maximum slip rate calculated at Point Arena is $25.5 \mathrm{~mm} / \mathrm{yr}$, in excellent agreement with the Olema data. The average slip per event at Point Arena implies a recurrence time of 200-400 years (Prentice, 
1989). Dated offset terrace deposits suggest that this rate has not changed by more than about $20 \%$ since Pliocene time (Prentice, 1989). The best age derived for the penultimate event is the mid 1600's (Schwartz et al., 1998), and the most likely ages for the previous three events were: \#3 1300 (post A.D. 1150, pre A.D. 1650), and two events pre A.D. 1210 and post A.D. 1, totaling five events in 2000 years (Prentice, 1989, 2000; Niemi and Zhang, 2000). Schwartz et al., 1998 also show an additional event at several sites in the early-mid 1500's.

A controversial aspect of Northern San Andreas tectonics has been whether the fault is segmented, with variable behavior for each segment, or whether the 1906 rupture was characteristic. The consistent slip rates found north of the Golden Gate, slow to about $17 \mathrm{~mm} / \mathrm{yr}$ south of the Golden Gate. This and a lower co-seismic slip south of the Golden Gate (Segall and Lisowski, 1990; Prentice and Ponti, 1997; Thatcher et al., 1997) led investigators to conclude that the fault is segmented near the Golden Gate. The Working Group on California Earthquake Probabilities (1990) applied a uniform slip rate to the fault, and concluded that segments with lower-co-seismic slip in 1906 should have more frequent events to fill the slip

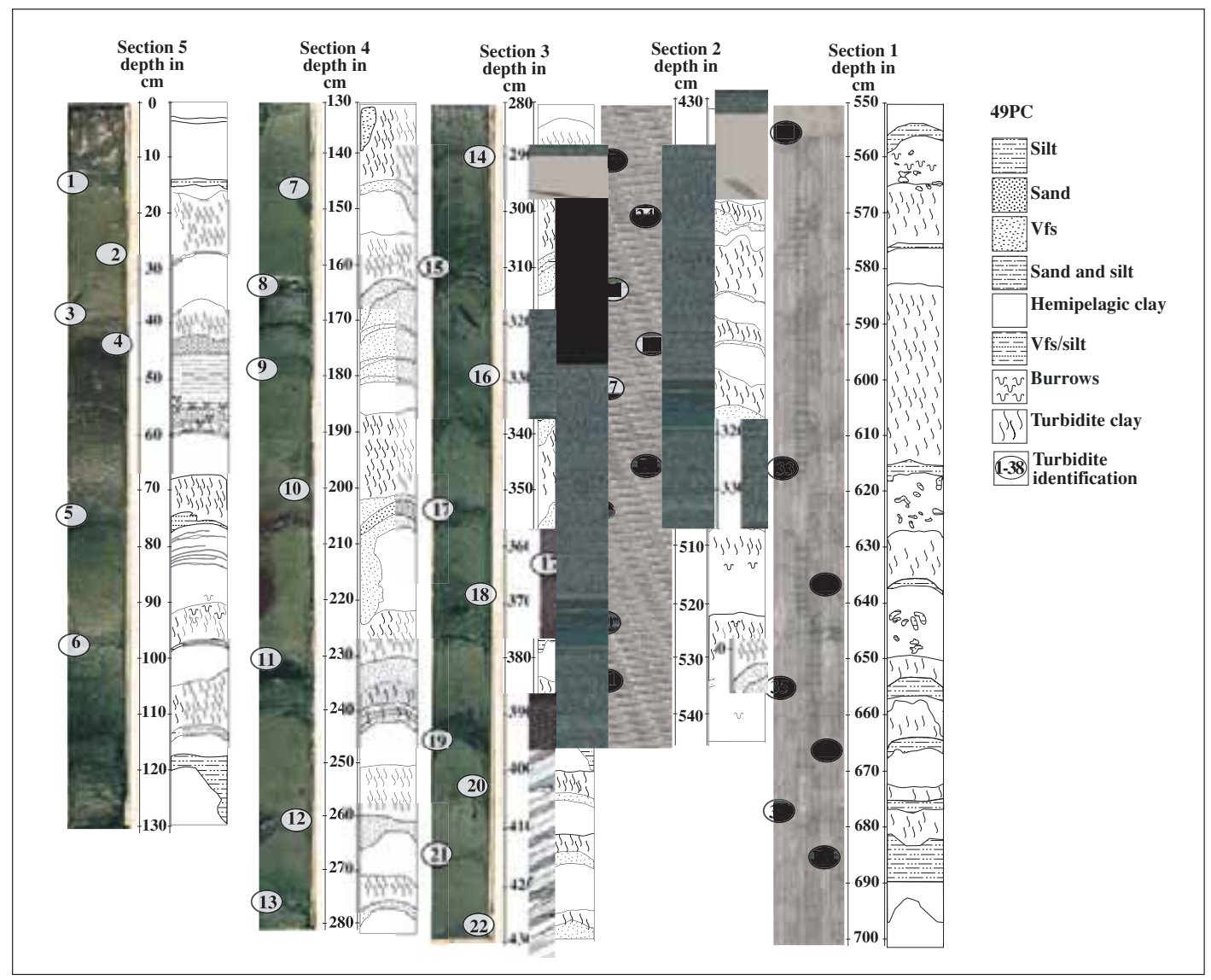

Fig. 10. Summary core logs and digital photographs of all sections of Noyo Channel core M9907-49PC. See fig. 9 for location. 
deficit. Schwartz et al. (1998) argues that the segmentation is simply a reflection that the offshore San Gregorio Fault (fig. 9) absorbs some of the slip, and the slip-rate on the main San Andreas is correspondingly reduced. They argue that the through-going rupture in 1906 was not segmented, and further, that the penultimate event, which occurred in the mid-1600's, ruptured approximately the same distance, and had a magnitude similar to the 1906 event.

\section{New results: Northern San Andreas turbidite record}

During our 1999 Cascadia cruise, we collected two piston cores and one box core from Noyo Channel, $150 \mathrm{~km}$ south of the southern end of the Cascadia subduction zone. We did this both to test the distance at which large ruptures would generate turbidites, and to investigate whether the Northern San Andreas had generated a turbidite record of its own. We found that the Noyo Channel cores near the offshore Northern San Andreas Fault do show a good cyclic record of turbidite beds (figs. 10 and 11a-d). In Core 49PC, we find thirty-one turbidite beds above the Holocene/Pleistocene faunal and lithologic «datum» as defined by Duncan et al. (1970), which Noyo Canyon has a ${ }^{14} \mathrm{C}$ age of $\sim 9000$ years BP.

Thus far, we have determined ages for 20 (of 38) events including the uppermost 5 events from cores 49PC/TC and adjacent box core 50 B.C. using AMS methods. The uppermost event returns a «modern» age, which we interpret is likely the 1906 San Andreas earthquake. The penultimate event returns an intercept age of A.D. 1664 ( $2 \sigma$ range 1505-1822). The third event and fourth event are lumped together, as there is no hemipelagic sediment between them. The age of this possible couplet event is A.D. 1524 (1445-1664). The couplet could represent two ruptures with little time between, an aftershock, or perhaps erosion at the base of T3. The fifth event age is A.D. 1204 (1057-1319), and the sixth event age is A.D. 1049 (981-1188). These results are in relatively good agreement with the onshore work to date which indicates an age for the penultimate event in the mid-1600's (figs. 9 and 11a-d), the most likely age for the third event of $\sim$ A.D. 1500-1600, and a fourth event A.D. 1300 . We presently do not have the spatial sampling needed to test for synchroneity of events along the Northern San Andreas, and thus cannot determine with confidence that the observed turbidite record is entirely earthquake generated. However, the good agreement in number of events between the onshore and offshore records suggests that either turbidite triggers other than earthquakes appear not to have added significantly to the turbidite record along the northernmost San Andreas margin during the last $\sim 2000$ years, or the similarity of records is a coincidence.

With ages for 20 events, we can begin to make some preliminary observations about the turbidite event history. Figure $12 \mathrm{~b}$ shows

Fig. 11a-d. a) Top $93 \mathrm{~cm}$ of trigger core M9907-49TC and (b) the gamma-ray and magnetic susceptibility logs (uncorrected) for the entire length $(700 \mathrm{~cm}$ ) of piston core M9907-49PC from Noyo Canyon. The characteristic low gamma and high magnetic susceptibility of the turbidite sands is used to identify and correlate turbidite events observed in the cores. c) A schematic core diagram of this piston core (49PC) is also shown. (Note correlation is from the piston core to the trigger core, thus depths of events do not match exactly because the trigger core has more compaction than the piston core). Of the 38 total events seen in the piston core, 31 are Holocene age. The youngest 7 events seen in the trigger core (a) correlate with the youngest 7 events of the piston core ( $\mathrm{b}$ and $\mathrm{c}$ ). The white buttons on the trigger core and the red horizontal lines on the log identify turbidite events. The recurrence times (c) of 216 and 234 years are calculated based on the age of T14 and the 1906 event. The Holocene-Pleistocene boundary is here defined at the 1 to 1 ratio of radiolarians to forams (Duncan et al. (1970); base of T31) is also apparent as a color change in the sediments, and is shown as the white curve near the bottom of (c). d) Sample core from the 1999 R/V Melville Cascadia Turbidite Paleoseismicity Cruise. The middle section of core shows the sharp color change from light grey to olive-green, characteristic of the Pleistocene-Holocene boundary, and several thin, grey turbidite sands (labeled with T's) separated by olivegreen hemipelagic mud. Note dropstones in the Pleistocene section. 


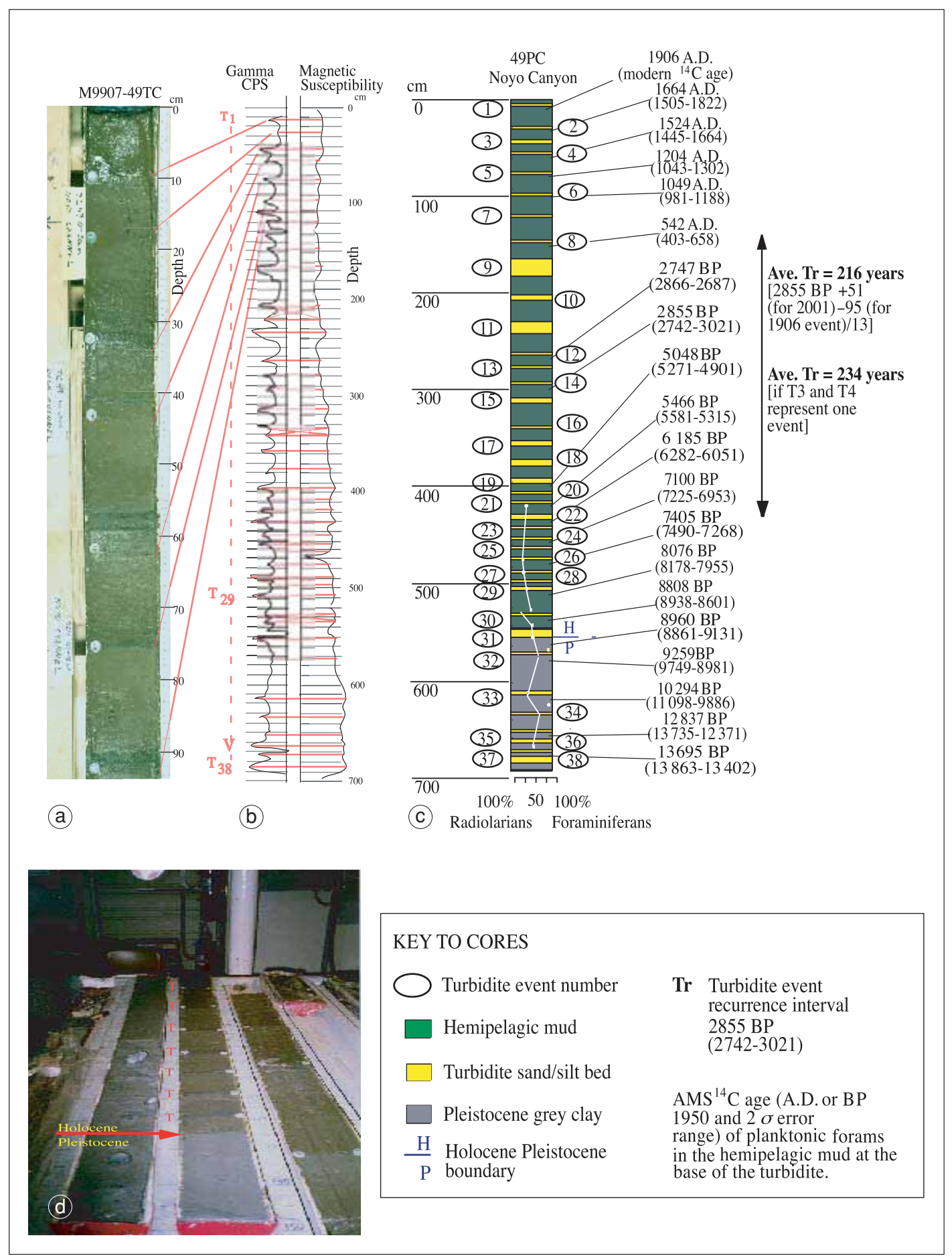




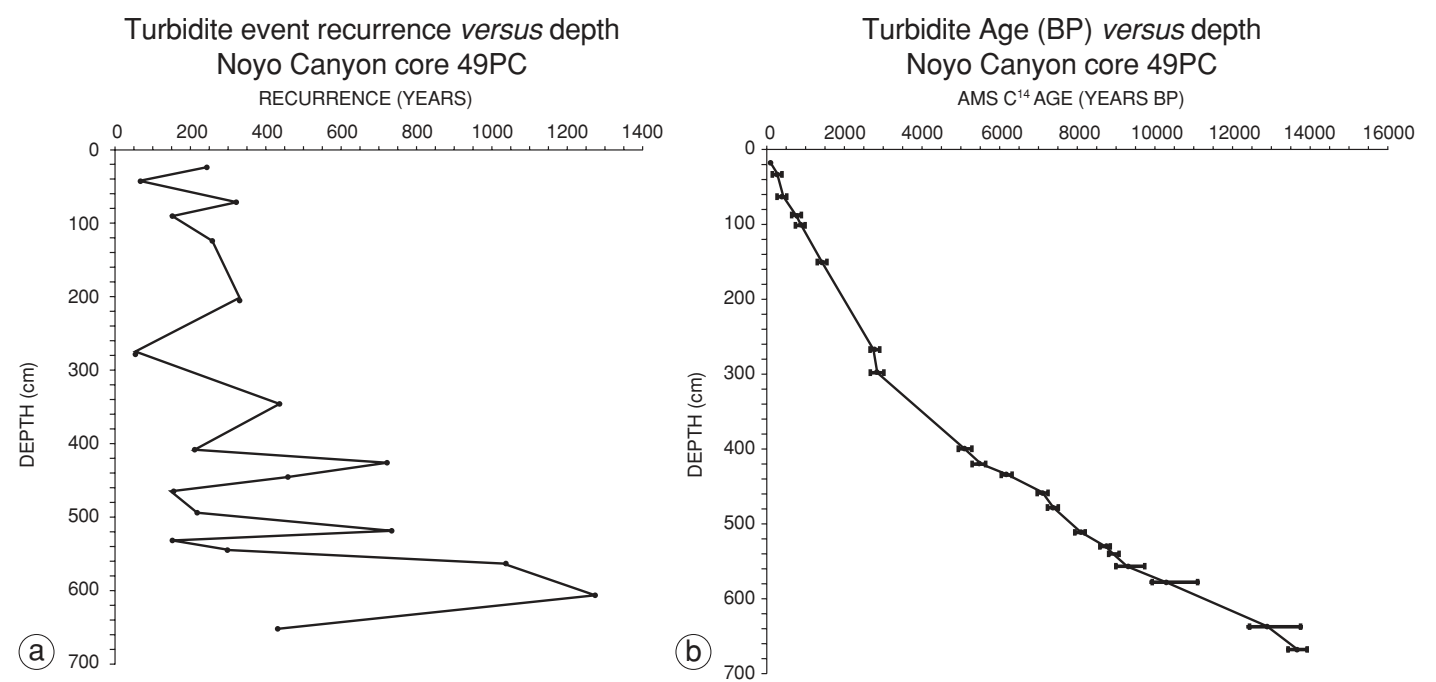

Fig. 12a,b. a) Event recurrence versus core depth for Noyo Canyon core 49PC. b) Event age versus depth in core 49PC. $2 \sigma$ errors for (b) shown by horizontal bars. Both plots show an increase in the interval between events down core. We cannot determine the origin of these rate changes with our single Noyo core. The youngest interval in (b) represents an average recurrence time of 216-234 (events 3 and 4 could be either 1 or 2 events). The good correspondence between these events and the land record suggests that this interval is most probably a good proxy for the Northern San Andreas earthquake record.

the age of the core with depth, and shows a good AMS age record, with no reversing intervals in those dated so far. Figure $12 \mathrm{a}$ shows the recurrence interval of events plotted with depth. It is apparent from both plots that both sedimentation rate and turbidite event frequency have not been constant through the Holocene. If the turbidite frequency is an earthquake proxy, then the repeat time for events along the northernmost segment near Noyo Canyon has decreased during the Holocene. This may be due to a number of possible causes: 1) the behavior of the fault has changed, for example more slip shifting from other parts of the plate boundary system to the main San Andreas in the Late Holocene; or 2) the record includes a non-earthquake climatic or sedimentation record that has changed through the Holocene. Climatic and sedimentation changes would tend to favor a reduction in sedimentation during the Holocene as sea level rose and separated canyons from their river sources, and terrestrial erosion rates fell. We observe just the opposite, with an increase in sedimentation rate (based on hemipelagic sediment between turbidites) that parallels the increase in turbidite frequency. This observation tends to support a change in fault behavior, however this issue cannot be resolved with our single core.

\section{Discussion}

As the Cascadia turbidite project has matured, we have learned a number of things about the subtleties of using turbidites to precisely date earthquakes. The most important is that regional and temporal correlations are the strongest evidence of earthquake triggering, and radiocarbon event ages are much less so. This is not surprising, and is simply the result of the errors and unknowns inherent in the dating process. Some of these problems have been known to land paleoseismologists for years; others are unique to the deep-sea environment. Our goals in radiocarbon dating have not been to use the ages to demon- 
strate earthquake origins, since the spatial and temporal correlations do a much better job. The purpose of the ages is to attempt a correlation with the land record, and to begin to integrate the two to cull more information about the earthquakes themselves in terms of the spatial and temporal patterns of strain release, about which we presently know very little.

Correlating paleoseismic events using the calibrated ages has long been the Achilles heel of paleoseismology. Because the ages themselves include many sources or error that must be propagated, it is sometimes difficult to get even known events to correlate this way. Land paleoseismologists have worked to overcome this problem by using large quantities of ages to be able to do statistical analyses of the «cloud» of data associated with each event to make the correlation more robust. With offshore data, we are unable to use that tool at present because the expense of collecting the original samples with a large ship has thus far precluded collecting enough sample volume to do more than one or two dates from each event. The limitation is imposed by the abundance of the planktonic forams that we are dating, of which there are just enough in one or two $4^{\prime \prime}$ diameter cores below each event for one or two ages. What we do have in the offshore record is a longer record at multiple locations. The tools that this provides offer another way to arrive at a robust record. As mentioned above, pattern matching offers a way to reveal a robust signal with less dependence on the individual data points, which may be in error for a variety of reasons. With multiple plots of recurrence, turbidite thickness, hemipelagic thickness, velocity, magnetic susceptibility etc., we can correlate events and do statistical analysis on the correlation of the curves. This can then be used in turn to identify outliers.

In fig. 8 we also show the land data from Willapa Bay (Atwater and Hemphill-Haley, 1997), a record from Lagoon Creek in Northern California (near the Klamath River, GarrisonLaney et al., 2002), Humboldt Bay (Clarke and Carver, 1992), and Southern Oregon (Kelsey et al., 2002). These records show similarities to the longer offshore record from Cascadia Basin, but it is too early to comment extensively. Our first complete core shows differences with events T2 and T3 of the onshore record, which we suspect may be due to the proximal environment of core 12PC. Previously we and others have noted a discrepancy between the average recurrence time seen in the marsh record, and the average recurrence time from the turbidite record. With a more complete record, we think that this apparent discrepancy may simply be an artifact of the different time spans being reported. Our average reported repeat time of $\sim 600$ years is for the 13 post-Mazama events. Now, with a complete record for one of our key cores, we see that if we calculate recurrence for the same time span that Atwater (1987) do, we get a very similar result. At Willapa Bay, Atwater and Hemphill-Haley (1997) report an average repeat time of 533 years (7 events in 3500 years); Kelsey et al. (2002) report 529 years for the Sixes River in Southern Oregon (11 events in 5500 years) and Garrison-Laney et al. (2002) report 608 years for Lagoon Creek. In our record for the youngest Holocene interval, we calculate an average recurrence of 490-550 years for the last $3500-4000$ years. Thus, it may be that at least for the last 3000-4000 years, there is no discrepancy, and thus it will be possible to correlate events one for one. This adds strength to both the land and offshore records in that input from independent upper plate earthquakes appear not to be significant at least for the data analyzed thus far for Washington, Oregon, and Northern California as far south as Humboldt Bay.

The curves show a possible anomaly in the 3000-4000 year range between the records in Southern Oregon, the coastal records to the north and south, and the turbidite record. As did Kelsey et al. (2002), we observe «extra» events in the onshore records from Bradley Lake and the Sixes River areas relative to both the onshore record and our turbidite record. Our Rogue Canyon cores directly sample the subduction zone events at this latitude, and the record of turbidites matches the other offshore records. The extra events in Bradley Lake suggest that Southern Oregon lakes and estuaries experience earthquakes or some other phenomenon that leaves similar records in addition to the regional great earthquake record. These could be upper plate events, smaller interplate events, or may possibly have some other origin. 


\section{Future directions}

If we can successfully calibrate our ages such that they are equivalent to event ages in the coastal marshes, we can find matches and mismatches in the two records which will lead to better understanding of both records. For example, some of the turbidite events are clearly larger than others, at least in terms of the thickness of the turbidite. Do these events correlate to larger onshore submergence, and or wider spatial recognition on land? Are they a result of a longer interval preceding that event, and thus more accumulated sediment was triggered? Or perhaps the longer interval ended in a larger earthquake as well. Two independent data sets allow a powerful analysis of these factors.

Moving toward a marine turbidite record that is both compatible with land records and calibrated properly has some complications, but resolution of these complications is possible, and will increase the resolution and utility of turbidites as earthquake proxies. Improvements in dating fall into two categories: 1) arriving at the best event age, and 2) calibrating the marine ages to be compatible with the land record. Arriving at the best event ages will involve removing or attempting to at least bracket some of the sources of error inherent in dating the events thus far. These include age bias induced by sampling below, not in each turbidite event. Since we do not date microfossils in the turbidites themselves because of potential reworking, we must date them either above or below each event. We date below the events because the transition where the fine-grained turbidite tail transitions to hemipelagic sedimentation is very subtle at times, and inconsistent, while the base of the turbidite is very distinct. The downside of this is that there may be basal erosion. We attempt to counter that by taking cores in nonerosive depositional environments such as distal channel reaches and the lee sides of point bars, but we are not always able to do that. Planktonic forams are thus collected from 2-3 $\mathrm{cm}$ intervals of sediment below each turbidite. The AMS age represents the midpoint of that interval, which is older than the event, thus we must correct for that. The correction however is also not simple, since we need to determine the local sedimentation rate (minus the turbidites which are instantaneous) for each event, or at least for an interval of time including that event. Final determination of hemipelagic sedimentation rates and these corrections await a future paper.

We also would like to assess and, if possible, make some correction for basal erosion, or at least identify events in cores that may have had some unknown amount of erosion. We can evaluate the ages that have suspected basal erosion effects by comparing the maximum thickness of hemipelagic sediment between each turbidite event. First, we can compare the multiple cores at each site to determine the maximum hemipelagic thickness found at each site for each of the turbidite events. Then we can compare the maximum hemipelagic thickness found at any site for each turbidite event (i.e. $\mathrm{T} 1, \mathrm{~T} 2$, etc.). If a sample for a radiocarbon age for a specific turbidite event (i.e. T5) has been taken at a site with less than the maximum hemipelagic thickness observed nearby, we will know that there has probably been basal erosion by the turbidity current at that site for that event.

The second category of corrections to make the marine cores compatible with land marsh and tree-ring ages involves the corrections applied to the radiocarbon ages themselves. Land ages are corrected to a calibration curve that is getting better with time as more data is used to compute the curves. Marine ages have an additional complication in that the exchange of air with the ocean is not instantaneous, even in surface waters, and thus the water has an «age» associated with it that must be removed. This is done using paired shell and wood dates from bays and estuaries that are incorporated into a marine database. This database has regional adjustments (Delta $\mathrm{R}$ ) that are made to the basic correction. In Cascadia, as in most regions, there are a number of calibration points along the coasts of Oregon, Washington, and California in the literature. The question is whether these values are valid for planktonic but pelagic (not estuarine) forams we use for AMS dating. To a first order, we know that contemporary values are not far off, since we get ages within 50-100 years for the \#1 event, which is 
known to be from the1700 A.D. earthquake (assuming acceptance of the premise of regional spatial and temporal correlation).

We are very fortunate that we have the 1700 earthquake because this known event offers the possibility of calibrating the Delta R correction. A related issue is that it is not known if the marine calibration corrections vary in time. We are again fortunate that we have not one, but two events of well determined age, the A.D. 1700 earthquake, and the eruption of Mt. Mazama. There was some delay between the eruption and the deposition of the turbidite, which makes this datum a bit less precise, however it still offers a calibration point better than any other available in the region. These two events cover much of the Holocene, and spatially include nearly all of Cascadia, offering a means to develop a calibration correction that accounts for both temporal and spatial variability to at least a first order for the Holocene.

\section{Conclusions}

Results from Cascadia thus far support the conclusion that 18 large earthquakes may have ruptured at least the northern $2 / 3$ of the plate boundary that we have examined. Synchronous triggering of turbid flows in several Washington channels has now been demonstrated for 18 events spanning the entire Holocene. Radiocarbon ages cannot prove or disprove synchronicity for the 18 events observed in other channels. While segmented rupture with close temporal spacing cannot be ruled out, the identical records found in the Rogue Channel would have to be produced by a remarkably consistent long-term rupture pattern, with essentially no variability through 18 events over 9850 years. We are also encouraged by the close agreement between preliminary data and the onshore paleoseismic record along the Northern San Andreas Fault. Preliminary results from Noyo Channel indicate the potential for applying this method, utilizing additional cores from other channels, to fully develop the Holocene event-history of the Northern San Andreas Fault System. Most importantly, by carefully correlating the turbidite and land records, it should be possible to construct reliable event records back 10000 years for Cascadia, the Northern San Andreas and other fault systems. Doing so would allow investigations of clustering, triggering and other recurrence models, which are presently difficult to test due to the relatively short instrumental, historical and onshore-paleoseismic records.

\section{Acknowledgements}

We thank the officers and crew of the Scripps Vessel R.V. Melville with special thanks to Bob Wilson. We thank the members of the Scientific Party: Drew Erickson, Mike Winkler, Pete Kalk, Julia Pastor, Antonio Camarero, Clara Morri, Gita Dunhill, Luis Ramos, Alex Raab, Nick Pisias Jr., Mark Pourmanoutscheri, David Van Rooij, Lawrence Amy, and Churn-Chi «Charles» Liu. This research was supported by National Science Foundation grants EAR-0001023, EAR-017120 and EAR-9803081 and U.S. Geological Survey National Earthquake Hazards Reduction Program award 01HQGR0051, and Cooperative Agreement 1434WR97AG00016. We also thank John Adams and Phil Barnes for thoughtful reviews that much improved the paper.

\section{REFERENCES}

ADAMS, J. (1985): The potential for subduction zone earthquakes in the Puget Sound, Washington area, Eos, Trans. Am. Geophys. Un., 66, 1071.

ADAMS, J. (1990): Paleoseismicity of the Cascadia subduction zone: evidence from turbidites off the OregonWashington margin, Tectonics, 9, 569-583.

ANASTASAKIS, G.C and D.J.W. PIPER (1991): The character of seismo-turbidites in the S-1 sapropel, Zakinthos and Strofadhes basins, Greece, Sedimentology, 38, 717-733.

Argus, D.F. and R.G. Gordon (1991): Current Sierra Nevada-North America motion from very long baseline interferometry: implications for the kinematics of the Western United States, Geology, 19,1085-1019.

ATWATER, B.F. (1987): Evidence for great Holocene earthquakes along the outer coast of Washington State, Science, 236, 942-944.

ATWATER, B.F. (1992): Geologic evidence for earthquakes during the past 2000 years along the Copalis River, southern coastal Washington, J. Geophys. Res., 97, 1901-1919.

Atwater, B.F. and E. Hemphill-Haley (1997): Recurrence 
intervals for great earthquakes of the past 3500 years at Northeastern Willapa Bay, Washington, U.S. Geol. Surv. Prof. Pap. 1576, pp. 108.

Atwater, B.F., A. Nelson, J.J. Clague, G.A. Carver, D.K. Yamaguchi, P.T. Bobrowsky, J. Bourgeois, M.E. Darienzo, W.C. Grant, E. Hemphill-Haley, H.M. Kelsey, G.C. Jacoby, S.P. Nishenko, S.P. Palmer, C.D. Peterson and M.A Reinhart (1995): Summary of coastal geologic evidence for past great earthquakes at the Cascadia subduction zone, Earthquake Spectra, 11, 1-18.

BRown, R.D. (1995): 1906 Surface faulting on the San Andreas Fault near Point Delgada, California, Bull. Seismol. Soc. Am., 85 (1), 100-110.

Castillo, D.A. and W.L. Ellsworth (1993): Seismotectonics of the San Andreas Fault System between Point Arena and Cape Mendocino in Northern California: implications for the development and evolution of a young transform, J. Geophys. Res., 98, 6543-6560.

Clague, J.J. (1997): Evidence for large earthquakes at the Cascadia subduction zone, Rev. Geophys., 35, 439-460.

Clarke, S.H. and G.A. CARVER (1992): Breadth of interplate coupling in the Southern Cascadia subduction zone: implication for earthquake magnitudes, Geol. Soc. Am. Abstr. Prog., 24, pp. 15.

Darienzo, M.E. and C.D. Peterson( 1990): Episodic tectonic subsidence of Late Holocene salt marshes, Northern Oregon Central Cascadia margin, Tectonics, 9, 1-22.

Duncan, J.R., G.A. Fowler and L.D. Kulm (1970): Planktonic Foraminiferan-Radiolarian ratios and Holocene-Late Pleistocene deep-sea stratigraphy off Oregon, Geol. Soc. Am. Bull., 81, 561-566.

FIELD, M.E. (1984): The Submarine Landslide of 1980 off Northern California, U.S. Geol. Surv. Circ., 938, 65-72.

Fumal T., G.F. Heingartner and D.P. Schwartz (1999): Timing and slip of large earthquakes on the San Andreas Fault, Santa Cruz Mountains, California, Geol. Soc. Am. Abstr. Prog., 31, A-56.

Garfield, N., T.A. Rago, K.J. Schnebele and C.A. Collins (1994): Evidence of a turbidity current in Monterey Submarine Canyon associated with the 1989 Loma Prieta earthquake, Cont. Shelf. Res., 14 (6), 673-686.

Garrison-Laney, C.E., H.F. Abramson and G.A. Carver (2002): Late Holocene tsunamis near the southern end of the Cascadia subduction zone, Seismol. Res. Lett.

GolDFINGER, C. and C.H. NELSON (1999): Holocene recurrence of Cascadia great earthquakes based on the Turbidite event record, Eos, Trans. Am. Geophys. Un., 80, 1024.

GoldFinger, C., C.H. Nelson and J. JohnSON (2003): Holocene earthquake records from the Cascadia subduction zone and Northern San Andreas Fault based on precise dating of offshore turbidites, Annu. Rev. Geophys., 31, 555-577.

Gorsline, D.S., T. De Diego and E.H. Nava-SANChEZ (2000): Seismically triggered turbidites in small margin basins: Alfonso Basin, Western Gulf of California and Santa Monica Basin, California Borderland, Sediment. Geol., 135, 21-35.

Grantz, A., R.L. Phillips, M.W. Mullen, S.W. Starratt, G.A. JONES, S.S. NAIDU and B.P. FINNEY (1996): Character, paleoenvironment, rate of accumulation, and evidence for seismic triggering of Holocene turbidites, Canada abyssal plain, Arctic Ocean, Mar. Geol., 133, 51-73.

GrigGS G.B. and L.D. Kulm (1970): Sedimentation in Cascadia. Deep-Sea Channel, Geol. Soc. Am. Bull., 81, 1361-1384.

Griggs, G.B., A.G. Carey and L.D. Kulm (1969): Deepsea sedimentation and sediment-fauna Interaction in Cascadia Channel and on Cascadia Abyssal Plain. Deep-Sea Res., 16, 157-170.

Hemphill-Haley, E. (1995): Diatom evidence for earthquake-induced subsidence and tsunami 300 years age in southern coastal Washington, Geol. Soc. Am. Bull., 107, 367-378.

Hemphill-Haley, E., A.R. Nelson, H.M. Kelsey and R.C. WITTER (2000): Displaced marine diatoms in a coastal fresh-water lake: microfossil evidence for Holocene tsunamis on the South-Central Oregon coast, in Proceedings of the Geological Society of America Penrose Conference on Great Cascadia Earthquake Tricentennial (Or. Dept. of Geol. Min. Ind.), edited by J. Clague, B. Atwater, K. Wang, M.M. Wand and I. WONG, p. 53.

Hutchinson, I., J.J. Clague, P.T. Bobrowsky and H.F.L. WiLliams (2000): Investigations of Cascadia paleoseismicity in southwestern B.C. and northernmost Washington State, in Proceedings of the Geological Society of America Penrose Conference on Great Cascadia Earthquake Tricentennial (Or. Dept. of Geol. Min. Ind.), edited by J. Clague, B. Atwater, K. Wang, M.M. WAND and I. WONG, p. 61.

Inouchi, Y., Y. Kinugasa, F. Kumon, S. Nakano, S. YASUMATSU and T. SHIKI (1996): Turbidites as records of intense palaeoearthquakes in Lake Biwa, Japan, Sediment. Geol., 104, 117-125.

JACOBY, G.C., D.E. BunKER and B.E. BENSON (1997): Treering evidence for an A.D. 1700 Cascadia earthquake in Washington and Northern Oregon, Geology, 25 (11), 999-1002.

Karlin, R.C. and S.E.B. Abella (1992): Paleoearthquakes in the Puget Sound region recorded in sediments from Lake Washington, U.S.A., Science, 258, 1617-1620.

KASTENS, K.A. (1984): Earthquakes as a triggering mechanism for debris flows and turbidites on the Calabrian Ridge, Mar. Geol., 55, 13-33.

Kelsey, H.M., R.C. Witter and E. Hemphill-Haley (1998): Response of a small Oregon estuary to coseismic subsidence and postseismic uplift in the past 300 years, Geology, 26.

Kelsey, H.M. R.C. WitTER and E. HemphILl-Haley (2002): Plate-boundary earthquakes and tsunamis of the past 5500 years, Sixes River estuary, Southern Oregon, Geol. Soc. Am. Bull., 114 (3), 298-314.

Lawson, A.C. (1908): The California earthquake of April 18, 1906, Rept. State Earthquake Invest. Comm. (Carnegie Institution, Washington D.C.), vols. I and II.

McLaughlin, R J., D.H SORg, J L MORTon, J N BatCHELDER, H.N. Heropoulos, H.N. OHLIN and M.B. NORMAN (1979): Timing of sulfide mineralization and elimination of the San Andreas Fault at Point Delgada, California, Eos, Trans. Am. Geophys. Union, 60 p. 883.

McLaughlin, R.J., K.R. LaJoie, D.H. Sorg, S.D. 
MORRISON and J.A. WOLFE (1983): Tectonic uplift of a middle Wisconsin marine platform near the Mendocino triple junction, California, Geology, 11, 35-39.

NAKAJIMA, T. and Y. KANAI (2000): Sedimentary features of seismoturbidites triggered by the 1983 and older historical earthquakes in the eastern margin of the Japan Sea, Sediment. Geol., 135, 1-19.

Nelson, A.R., B.F. Atwater, P.T. Brobowski, L.A. Bradley, J.J. Clague, G. Carve, M.E. Darienzo, W.C. Grant, H.W. Krueger, R. Sparks, T.W. STAFFORD and M. StUIVER (1995): Radiocarbon evidence for extensive plate-boundary rupture about 300 years ago at the Cascadia subduction zone, Nature, 378, 371-374.

Nelson, A.R., H.M. Kelsey, E. Hemphill-Haley and R.C WITTER (2000): Oxcal analyses and varve-based sedimentation rates constrain the times of $\mathrm{C}^{14}$ dated tsunamis in Southern Oregon, in Proceedings of the Geological Society of America Penrose Conference on Great Cascadia Earthquake Tricentennial (Or. Dept. of Geol. Min. Ind.), edited by J. Clague, B. Atwater, K. Wang, M.M. WAND and I. WONG, 71-72.

Nelson, C.H. (1968): Marine geology of Astoria deep-sea fan, Ph.D. Thesis, Oregon State University, Corvallis, p. 289.

Nelson, C.H. and C. GoldFinger (1999): Turbidite event stratigraphy and implications for Cascadia basin paleoseismicity, Eos, Trans. Am. Geophys. Un., 80, 733-734.

Nelson, C.H., B. Savoye, J.P. Rehault and C. Escutia (1995): Interfingering of Western Corsican margin aprons with the Var Fan lobe and an apparent Late Quaternary Corsican paleoseismic event, in International Association of Sedimentologists 16th Regional European Meeting, Aix-les-Bains, Savoie France, Abstracts volume, p. 113

Nelson, C.H. C Goldfinger, J.E. Johnson and G. DunHILL (2003): Paleoseismic history of the Cascadia subduction zone derived from turbidite stratigraphy, U.S. Geol. Surv. Prof. Pap. (in review).

NiEMI, T.M. and N.T. HALL (1992): Late Holocene slip rate and recurrence of great earthquakes on the San Andreas Fault in Northern California, Geology, 20, 195-198.

NiEmI, T.M. and Z. BeN-Avraham (1994): Evidence for Jericho earthquakes from slumped sediments of the Jordan River delta in the Dead Sea, Geology, 22 , 395-398.

Niemi, T. and H. Zhang (2000): Paleoseismology of the Northern San Andreas Fault at the Vendanta marsh site, Marin County, CA, in 3rd Conference on Tectonic Problem of the San Andreas Fault System, Stanford University, California (abstract)

Ollerhead, J., D.J. Huntley, A.R. Nelson and H.M. KeLSEY (2001): Optical dating of tsunami-laid sand from an Oregon coastal lake, Quat. Sci. Rev., 20 (18), 1915-1926.

Oppenheimer, D., G. Beroza, G. Carver, L. Dengler, J. Eaton, L. Gee, F. Gonzalez, A. Jayko, W.H. Li, M. Lisowski, M. Magee, G. Marshall, M. Murray, R. McPherson, B. Romanowicz, K. Satake, R. Simpson, P. Somerville, R. Stein and D.VAlentine (1993): The Cape Mendocino, California, earthquakes of April 1992: subduction at the triple junction, Science, 261, 433-438.
Pilkey, O.H. (1988): Basin plains; giant sedimentation events, Geol. Soc. Am. Spec. Pap., 229, 93-99.

PRENTICE, C.S. (1989): Earthquake geology of the Northern San Andreas Fault near Point Arena, California, Ph.D. Thesis, California Inst. Tech., Pasadena, pp. 252.

PrentiCE, C.S. and D.J. PonTi (1997): Coseismic deformation of the Wrights tunnel during the 1906 San Francisco earthquake: a key to understanding 1906 fault slip and 1989 surface ruptures in the Southern Santa Cruz Mountains, California, J. Geophys. Res., 102, 635-648.

Prentice, C.S., D.J. Merritts, E.C. Beutner, P. Bodin, A. SCHILL and J.R. MulleR (1999): Northern San Andreas Fault near Shelter Cove, California, Geol. Soc. Am. Bull., 111, 512-523.

Prentice, C., R. Langridge and D. Merritts (2000): Paleoseismic and Quaternary tectonic studies of the San Andreas Fault from Shelter cove to Fort Ross, in 3 rd Conference Tectonic Problems of the San Andreas Fault System, edited by R.L. KovaCH and G. BoKELMANN, Stanford University, California.

Satake, K., K. Shimazaki, Y. Tsuji and K. Ueda (1996): Time and size of a giant earthquake in Cascadia inferred from Japanese tsunami records of January, 1700, Nature, 379, 246-249.

Sauber, J.W., W. Thatcher, S.C. Solomon and M. LISOWSKI (1994): Geodetic slip-rate for the Eastern California shear zone and the recurrence time for Mojave desert earthquakes, Nature, 367, 264-266.

Schwartz, D.P. D. Pantosti, K. Okumura, T.J. Powers and J.C. Hamilton (1998): Paleoseismic investigations in the Santa Cruz mountains, California: implications for recurrence of large-magnitude earthquakes on the San Andreas Fault, J. Geophys. Res., 103 (8), 17,985-18,001.

SEgall, P. and M. LisowsKi (1990): Surface displacement in the 1906 and 1989 Loma Prieta earthquakes, Science, 250, 1241-1244.

Shiki, T., F. Kumon, Y. Inouchi, Y. Kontani, T. Sakamoto, M. Tateishi, H. Matsubara and K. FuKUYAMA (2000) Sedimentary features of the seismo-turbidites, Lake Biwa, Japan, Sediment. Geol., 135, 37-50.

Southon, J.R., D.E. Nelson and J.S. Vogel (1990): A record of past ocean-atmosphere radiocarbon differences from the Northeast Pacific, Paleoceanography, 5 (2), 197-206

SteIN, R.S., G.C.P. KING and J. LIN (1992): Change in failure stress on the Southern San Andreas Fault System caused by the 1992 M 7.4 Landers earthquake, Science, 199, 1328-1332.

StuviER, M. and T.F. BRAZIUnAs (1993): Modeling atmospheric ${ }^{14} \mathrm{C}$ influences and ${ }^{14} \mathrm{C}$ ages of marine samples to 10000 B.C., Radiocarbon, 35, 137-189.

Thatcher, W., G. Marshall and M. Lisowski (1997): Resolution of fault slip along the $470 \mathrm{~km}$ long rupture of the great 1906 San Francisco earthquake, $J$. Geophys. Res., 102, 5353-5367.

Thomson, J. and P.P.E. WeAVER (1994): An AMS radiocarbon method to determine the emplacement time of recent deep-sea turbidites, Sediment. Geol., 89, $1-7$.

WARD, S.N. and S.D.B. GoES (1993): How regularly do earth- 
quakes recur? A synthetic seismicity model for the San Andreas Fault, Geophys. Res. Lett., 20 (19), 2131-2134.

Working Group on NORTHERN CALIFORNIA EARTHOUAKE Potential (1990): Probabilities of large earthquakes in the San Francisco Bay region, California, U.S. Geol. Surv. Circ. 1053, pp. 53.
Yamaguchi, D.K., B.F., Atwater, D.E. Bunker, B.E. BENSON and M.S. REID (1997): Tree-ring dating the 1700 Cascadia earthquake, Nature, 389, 922-923.

ZdANOwiCZ, C.M., G.A. ZiELINSKI and M.S. GERMANI (1999): Mount Mazama eruption: Calendrical age verified and atmospheric impact assessed, Geology, 27, 621-624. 